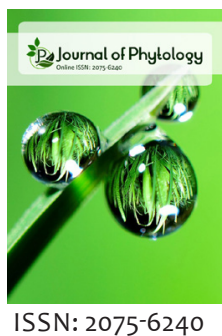

Received: September 14, 2020 Revised: November 07, 2020 Accepted: November 11, 2020 Published: November 19, 2020

*Corresponding Author: Mohammad Anwar Hossain Email: anwargpb@bau.edu.bd

\section{Potential determinants of salinity tolerance in rice (Oryza sativa L.) and modulation of tolerance by exogenous ascorbic acid application}

\author{
Md. Musfiqur Rahman', Israt Jahan', Md. Mahmud Al Noor², \\ Mst. Fatema Tuzzohora', Abdullah Al Mamun Sohag', Sharif-Ar-Raffi', \\ Mirza Moffazzal Islam², David J. Burritt4, Mohammad Anwar Hossain** \\ 'Department of Genetics and Plant Breeding, Bangladesh Agricultural University, Mymensingh-2202, Bangladesh, \\ 2Plant Breeding Division, Bangladesh Institute of Nuclear Agriculture, Bangladesh Agricultural University Campus, \\ Mymensingh, Bangladesh, ${ }^{3}$ Department of Biochemistry and Molecular Biology, Bangladesh Agricultural University, \\ Mymensingh-2202, Bangladesh, ${ }^{4}$ Department of Botany, The University of Otago, Dunedin 9016, New Zealand
}

\begin{abstract}
Rice is a relatively salt-sensitive crop with the reproductive and seedling stages being the most sensitive. Two separate experiments were conducted to isolate potential determinants of salinity tolerance and to investigate the possibility of modulating salt tolerance by exogenous ascorbic acid (AsA) application. Rice plants were imposed to salinity $\left(\mathrm{EC}=10.0 \mathrm{dS} \mathrm{m} \mathrm{m}^{-1}\right)$ both at the seedling and reproductive phases of growth. Salinity at the seedling stage resulted a sharp decline in shoot and root growth related traits including leaf chlorophyll content, while hydrogen peroxide $\left(\mathrm{H}_{2} \mathrm{O}_{2}\right)$ and malondialdehyde (MDA) levels increased. Plants experienced with salinity at the reproductive phases of growth showed a significant reduction in yield attributing traits while the tissue levels of $\mathrm{H}_{2} \mathrm{O}_{2}$ increased. Exogenous AsA application reversed the negative impact of salt stress, modulating the root and shoots growth and yield related traits and lowering $\mathrm{H}_{2} \mathrm{O}_{2}$ and MDA levels. FL-478 was identified as the most tolerant genotype at the seedling stage, with Binadhan-10 being the most tolerant at the reproductive stage. Grain yield panicle ${ }^{-1}$ significantly and positively corrected with number of filled grains panicle ${ }^{-1}$, panicle length, plant height, and spikelet fertility, and negatively correlated with $\mathrm{H}_{2} \mathrm{O}_{2}$ levels. Stress tolerance indices clearly separated the tolerant and susceptible genotypes. A principal component analysis revealed that the first two components explained $87 \%$ of the total variation among the genotypes. Breeding efforts could therefore to undertake for developing salinity tolerance by manipulating endogenous AsA content in rice.
\end{abstract}

KEYWORDS: Rice, Ascorbic Acid, Salt Stress, Oxidative Stress, Seedling Stage, Reproductive stage

\section{INTRODUCTION}

Saline soils are one of the most severe constraints to crop productivity worldwide and thus are a major concern for global food security [1].It has been projected that more than $20 \%$ of the world's arable land and $50 \%$ of irrigated areas, which include around $30 \%$ of rice growing areas, already suffer from salinity problems [2]. To feed an increasing global population, it will be essential to utilize these saline soils either by using reclamation to reduce salinity or by growing salt tolerant crop plant [3]. Conventional plant breeding to increase crop yields in saline environments is often slow, due to our poor understanding of the molecular and genetic mechanisms of salt stress tolerance as well as lack of suitable phenotyping and genotyping techniques [4].
Hence, there is a pressing need to improve our understanding of the complex mechanisms associated with salt tolerance, as well as to develop appropriate phenotyping and genotyping techniques to be used for the development of modern crop varieties that are more resilient to salt stress. An understanding of salinity tolerance mechanisms at the various phases of plant development and identification of potential traits associated with salt stress determinants by using genotypes with variable degrees of salt stress tolerance will enable us to develop robust salt tolerant crop varieties or management techniques for sustainable crop production [5].

Rice (Oryza sativa L.) is an essential crop that provides food for more than half of the world population. It is the staple

Copyright: $\odot$ The authors. This article is open access and licensed under the terms of the Creative Commons Attribution License (http://creativecommons.org/licenses/by/4.0/) which permits unrestricted, use, distribution and reproduction in any medium, or format for any purpose, even commercially provided the work is properly cited. Attribution - You must give appropriate credit, provide a link to the license, and indicate if changes were made. 
food of most people in Bangladesh and it is the world's second most important grain. In Bangladesh, rice occupies about $70 \%$ of the total cropped area, about 13.9 million hectares. Of the 2.85 million hectares of coastal arable land about 1.056 million hectares are affected by various salinity levels and crop production in those areas is very limited [6]. Importantly, it has also been predicted that increases in soil salinity may lead to a decline in rice yield by $15.6 \%$ by 2050 [7]. So, there is a critical need for developing rice varieties that can withstand high levels of salt stress and maintain satisfactory yields under both saline and non-saline conditions.

Rice is relatively tolerant to stress during seed germination, active tillering, and at maturity but is very sensitive at the early seedling stage and at the reproductive stage [2,8]. Very poor correlation exists between tolerance at the reproductive and seedling stages, suggesting that these two sensitive stages are independent of each other and are controlled by dissimilar sets of genes [9]. Despite much research having been conducted for the salt tolerance at the seedling stage very little attention has been paid to the reproductive stage, although the reproductive stage is most decisive as it finally governs grain yield [10]. This is mainly because of a lack of reliable reproductive-stage-specific phenotyping protocols [2].

Salinity imposes ionic and osmotic stresses on plants [11] and increased levels of reactive oxygen species (ROS), such as hydrogen peroxide $\left(\mathrm{H}_{2} \mathrm{O}_{2}\right)$, superoxide $\left(\mathrm{O}_{2}{ }^{-}\right)$and hydroxyl radical, and this ultimately leads to oxidative stress [12-14]. Consequently, metabolic dysfunction and damage to cellular structures, inhibition of photosynthesis contribute to growth perturbances, reduced fertility, and premature senescence in plants [15]. The most injurious effect of salinity, at the reproductive stage, is on panicle initiation, pollen viability, spikelet formation, pollen germination and fertilization, and significant effects have been observed on panicle weight, panicle length, primary branches panicle ${ }^{-1}$, number of filled grains panicle $^{-1}$, number of unfilled grains panicle ${ }^{-1}$, total grain number panicle $^{-1}$, total grain weight panicle ${ }^{-1}, 1000$-seed weight and total grains plant ${ }^{-1}$ [16-18]. Though pollen and spikelet fertility and pollen germination are the most important determinates of rice yields under salt stress $[19,20]$, there are no comprehensive reports concerning the relationship between ROS metabolism and pollen or spikelet fertility in response to salinity, although high $\mathrm{Na}^{+}$concentrations are known to be associated with pollen sterility [21]. Importantly, drought induced spikelet sterility was reported to be associated with an abrupt increase in ROS and/ or inefficient antioxidant defenses [22]. Enhanced antioxidant defense is one of the mechanisms plants use to adapt to adverse environments, including salt stress [13-14, 23]. Changes in the amount and the activities of antioxidant enzymes in response to salinity were found to differ between salt sensitive and tolerant cultivars of various crop plants $[23,24]$. While several studies have been conducted to decipher the mechanisms of salt tolerance at the seedling stage, little emphasis has been given to the biochemical mechanisms of salinity tolerance during panicle initiation and flowering. Therefore, assessment of popular salt tolerant and high yielding rice varieties, tolerant breeding lines and sensitive varieties, for spikelet fertility in relation to ROS metabolism could open up new possibilities to breed rice varieties for higher salt tolerance.

Ascorbic acid (AsA) is a highly water-soluble antioxidant molecules and plays a vital role in plant defense, including ROS detoxification through the ascorbate-glutathione pathway and through cellular signalling that triggers adaptive responses [25]. Optimum levels of glutathione and AsA were found to improve the overall productivity of plants through the modulation of osmoregulation, water use efficiency, photosynthetic performance and plant water and nutrient utilization efficiency [25]. Under stressful conditions higher rates of AsA degradation have been observed and without increased rates biosynthesis this can cause an imbalance in cell redox homeostasis [26-27]. Exogenous application of AsA was found to improve salt tolerance in various crop plants through protection of lipids and proteins from oxidative damage, particularly at seedling stage [28-30]. Transgenic plants over-expressing AsA biosynthetic pathway genes have been shown to possess higher abiotic stress tolerance, including salinity tolerance, by improving ROS and methylglyoxal(MG) detoxification [31-33]; however, many aspects of the role of exogenous AsA in modulating salt stress tolerance particularly at reproductive phase is remain unknown. In rice, research related to spikelet fertility/sterility in relation to salt-induced ROS accumulation and AsA metabolism is unknown. Considering the above, the present research was conducted to identify potential morphological and biochemical determinants and stress tolerance indices in rice at the seedling and reproductive stages, using contrasting genotypes having difference in salinity tolerance, using an appropriate phenotyping protocol. The potential of exogenous AsA-mediated salt stress tolerance was also investigated as an addition to future breeding strategies.

\section{MATERIALS AND METHODS}

\section{Plant Materials}

Seven diverse rice genotypes including one salt tolerant advanced breeding line (FL-478), two salt sensitive varieties (Binadhan-6, BRRI dhan28), and four moderately salt tolerant varieties (Binadhan-8, Binadhan-10, BRRI dhan67, BRRI dhan78) were used as plant materials.

\section{Seedlings Growth Conditions and Salt Stress Treatments}

Two separate experiments were conducted with four replications and four treatments (viz., control, $2 \mathrm{mM}$ AsA, salinity ( $\mathrm{EC}=10.0$ $\mathrm{dSm}^{-1}$ ) and salinity $+2 \mathrm{mM}$ AsA) under a completely randomized design (CRD). In experiment I, rice seedlings were cultured in professional peter solution under hydroponic condition. After 13 days of seedling growth, two groups of seedlings of each genotype were pre-treated with $2 \mathrm{mM}$ AsA in peter solution for $24 \mathrm{~h}$. After 14 days of seedling growth, AsA pre-treated and untreated seedlings were then imposed to salinity $\left(10 \mathrm{dS} \mathrm{m}^{-1}\right.$ $\mathrm{NaCl}$ solution) in hydroponic peter solution for 96 hours. The other group of AsA pre-treated seedlings was also grown under control condition. 
In experiment II, rice plants were grown in perforated pots filled with field soil and at the end of the rice growth stage 4 (young panicle about to emerge from flag leaf) two groups of rice plants of each genotype were pruned, leaving the penultimate leaf and flag leaf, and then subjected to $10 \mathrm{dS} \mathrm{m}^{-1}$ salt stress in hydroponic tank and allowed to grow up to the ripening stage [2]. One group of salt-stressed rice plants and one group of control rice plants were sprayed with a $2 \mathrm{mM}$ AsA solution containing $0.001 \%$ Tween-20, using a hand sprayer, after 2 days and 4 days of salinity treatment. The same amount of distilled water was sprayed onto control plants.

\section{Data on Morphological Traits Recorded at the Seedling and Reproductive Stage}

In experiment I, data on shoot length, root length, fresh root weight, and fresh shoot weight were calculated from ten seedlings per genotype for each replication. Data on dry root weight and dry shoot weight were estimated after oven-drying of the samples at $60^{\circ} \mathrm{C}$ for 3 days.

In experiment II, data on yield and yield attributing traits (days to maturity, panicle length, plant height, number of unfilled grains panicle ${ }^{-1}$, number of filled grains panicle ${ }^{-1}$, spikelet fertility (\%), 100-seed weight, grain yield panicle ${ }^{-1}$ ) were recorded from ten plants replication ${ }^{-1}$ for each genotype, after harvesting. Data on $\mathrm{H}_{2} \mathrm{O}_{2}$ was measured from flag leaf tissues after 8 days of salt stress.

\section{Determination of Chlorophyll Content}

Chlorophyll content was determined from leaf tissues $(0.5 \mathrm{~g})$ of the seedlings by soaking in $80 \%$ acetone as described by Sohag et al. [34]. The absorbance of the acetone extracts was measured at 645 and 663 using a UV-VIS spectrophotometer (Shimadzu, UV-1201, Japan). The total chlorophyll content was expressed as $\mathrm{mg} \mathrm{g}^{-1} \mathrm{FW}$.

\section{Determination of Hydrogen Peroxide $\left(\mathrm{H}_{2} \mathrm{O}_{2}\right)$}

Hydrogen peroxide from leaf tissues at the seedling stage and from flag leaf tissues at the reproductive stage was measured following the method of Velikova et al. [35] and the $\mathrm{H}_{2} \mathrm{O}_{2}$ content was calculated by utilizing $0.28 \mu \mathrm{M}^{-1} \mathrm{~cm}^{-1}$ extinction coefficient [36].

\section{Determination of Malondialdehyde (MDA)}

MDA was measured from leaf tissues (at seedling stage) following the standard method as described by Heath and packer [37] and the MDA content was determined utilizing $155 \mathrm{mM}^{-1} \mathrm{~cm}^{-1}$ extinction coefficient and expressed as nmolg-1 FW [38].

\section{Stress Tolerance Indices}

Different indices of stress tolerance were calculated based on the data on grain yield panicle ${ }^{-1}$ using following equations:
$\mathrm{SSI}=\left(1-\left(\mathrm{Ys}_{\mathrm{S}} / \mathrm{Y} \mathrm{P}\right)\right) /\left(1-\left(\overline{\mathrm{Y}}_{\mathrm{S}} / \overline{\mathrm{Y}}_{\mathrm{P}}\right)\right)$ according to Fisher and Maurer [39]

$\mathrm{TOL}=\mathrm{Yp}-\mathrm{Ys}$ according to Rosielle and Hamblin [40]

$\mathrm{STI}=(\mathrm{Yp} \times \mathrm{Ys}) /(\overline{\mathrm{Y}} \mathrm{p})^{2}$ according to Fernandez [41]

$\mathrm{YSI}=\mathrm{Ys} / \mathrm{Yp}$ according to Bouslama and Schapaugh [42]

Where, in all above equations, Ys and Yp are stress and normal yield panicle $\mathrm{e}^{-1}$ of a given genotype, respectively. $\overline{\mathrm{Y}} \mathrm{S}$ and $\mathrm{Y} \mathrm{p}$ are average yield of all genotypes under stress and normal conditions, respectively.

\section{Statistical Analysis}

Data analysis was carried out using the Minitab 17 statistical software package (Minitab Inc. State College, Pennsylvania) or $\mathrm{R}$, version 3.3.2. A one-way analysis of variance was carried following CRD design with two factors in mixed model, in which replicates were random and factors were fixed. Significant difference in treatment means was tested at $P<0.05$ level using Tukey's multiple comparison test. Principal component analysis (PCA) and phenotypic correlation co-efficient was done using Minitab 17 statistical software.

\section{RESULTS}

\section{Effect of AsA, Salt Stress and Salt+2mM AsA Treatments on Rice Genotypes at the Seedling Stage}

The results of analysis of variance for all the characters (viz., root length, shoot length, fresh root weight, fresh shoot weight, dry root weight, dry shoot weight, total chlorophyll, $\mathrm{H}_{2} \mathrm{O}_{2}$, MDA) showed highly significant $(P \leq 0.001)$ variations due to genotypes as well as treatments (Supp. Table 1). Root length, shoot length, fresh shoot weight, dry root weight, dry shoot weight, total chlorophyll, $\mathrm{H}_{2} \mathrm{O}_{2}$, MDA were found to have significant $(P \leq 0.001) \mathrm{G} \times \mathrm{T}$ interactions, whereas shoot fresh weight showed no significant $\mathrm{G} \times \mathrm{T}$ interaction (Supp. Table 1).

\section{Root Length}

The greatest root length under control conditions was found for BRRI dhan28 $(12.23 \mathrm{~cm})$, whereas the lowest was found for Binadhan-8 $(7.32 \mathrm{~cm})$ (Table 1). Root length showed a significant decrease under salt stress in comparison with control for all the genotypes studied. The greatest reduction was observed in salt susceptible Binadhan-6 (15.51\%), whereas the least reduction was found for Binadhan-10 (0.19\%) (Table 1). In response to exogenous AsA pre-treatment, the salt susceptible variety Binadhan- 6 showed the greatest increase in root length $(14.70 \%)$, followed by BRRI dhan28, BRRI dhan67, BRRI dhan78, Binadhan-10, Binadhan-8 and FL-478 $(10.53,5.96,5.55,2.82,1.08$ and $0.42 \%$, respectively), in comparison with the seedlings imposed to salinity without AsA pretreatment. Importantly, exogenous AsA pre-treated nonstressed seedlings have showed no significant increase in root length in comparison with control (Table 1). 
Table 1: Effects of exogenous AsA on different morphological and biochemical traits of seven rice genotypes grown under salt stress condition at the seedling stage. Data are presented with mean values of four independent replicates. Different letters in the same column indicate significant differences between the treatments at $p<0.05$ level using the Tukey's multiple comparison tests. Control (Peter solution), AsA (2mM AsA in Peter solution), Salt (10.0 dSm${ }^{-1}$ in Peter solution), Salt+AsA (10.0 dSm-1 $+2 \mathrm{mM}^{-1}$ AsA in Peter solution)

\begin{tabular}{|c|c|c|c|c|c|c|c|c|c|c|}
\hline $\begin{array}{l}\text { Genotype } \times \\
\text { Treatment }\end{array}$ & & $\begin{array}{l}\text { Root length } \\
\text { (cm) }\end{array}$ & $\begin{array}{l}\text { Shoot } \\
\text { Length } \\
(\mathrm{cm})\end{array}$ & $\begin{array}{c}\text { Root fresh } \\
\text { weight } \\
\text { (mg) }\end{array}$ & $\begin{array}{l}\text { Shoot fresh } \\
\text { weight (mg) }\end{array}$ & $\begin{array}{l}\text { Root dry } \\
\text { weight } \\
\text { (mg) }\end{array}$ & $\begin{array}{l}\text { Shoot dry } \\
\text { weight } \\
(\mathrm{mg})\end{array}$ & $\begin{array}{c}\text { Total } \\
\text { chlorophyll } \\
\left(\mathrm{mg} \mathrm{g}^{-1} \mathrm{FW}\right)\end{array}$ & $\begin{array}{c}\mathrm{H}_{2} \mathrm{O}_{2} \\
\left(\mathrm{nmol} \mathrm{g}{ }^{-1} \mathrm{FW}\right)\end{array}$ & $\begin{array}{c}\text { MDA } \\
\left(\mathrm{nmol} \mathrm{g}{ }^{-1} \mathrm{FW}\right)\end{array}$ \\
\hline \multirow[t]{4}{*}{ FL-478 } & Control & $10.15 \mathrm{ef}$ & $31.74 a$ & $166.67 a$ & $460.00 a$ & $42.00 \mathrm{a}$ & $72.33 a$ & $1.87 \mathrm{c}-\mathrm{e}$ & $35.41 \mathrm{e}-\mathrm{g}$ & $28.55 \mathrm{kl}$ \\
\hline & AsA & $10.17 d-f$ & $32.19 a$ & $160.00 \mathrm{ab}$ & $450.00 a$ & $37.67 b$ & $70.33 a b$ & $1.95 b c$ & $37.14 d-f$ & $24.63 \mathrm{mn}$ \\
\hline & Salt & $9.45 \mathrm{fg}$ & $27.82 b c$ & $130.00 \mathrm{c}-\mathrm{g}$ & $303.33 d$ & $25.00 \mathrm{~cd}$ & $62.00 \mathrm{~cd}$ & $1.58 \mathrm{~h}-\mathrm{j}$ & $41.55 b c$ & 34.5lhi \\
\hline & Salt + AsA & $9.49 f$ & $28.84 b$ & $154.00 a-c$ & $326.67 \mathrm{~cd}$ & $27.33 c$ & $65.67 b c$ & $1.79 d-f$ & $39.23 \mathrm{~cd}$ & $30.54 j k$ \\
\hline \multirow[t]{4}{*}{ Binadhan-6 } & Control & $10.31 \mathrm{de}$ & $26.08 c-f$ & $110.00 f-j$ & $316.67 \mathrm{~cd}$ & $22.99 \mathrm{de}$ & $49.68 f g$ & $1.88 \mathrm{~cd}$ & $33.60 \mathrm{~g}-\mathrm{i}$ & 33.74hi \\
\hline & AsA & $10.46 c-e$ & $26.38 c-e$ & $113.33 \mathrm{e}-\mathrm{i}$ & $296.67 d$ & $22.67 \mathrm{de}$ & $45.67 g-i$ & $1.94 b c$ & $29.19 k-n$ & $29.50 k$ \\
\hline & Salt & $8.71 \mathrm{~g}$ & $20.80 k$ & $83.33 \mathrm{j}-1$ & $143.33 \mathrm{j}$ & 17.00h-m & $34.33 \mathrm{kl}$ & $1.331 \mathrm{~m}$ & $45.09 a$ & $58.24 a b$ \\
\hline & Salt + AsA & $9.99 \mathrm{ef}$ & $22.35 \mathrm{~h}-\mathrm{k}$ & 100.00h-k & $176.67 \mathrm{~h}-\mathrm{j}$ & $20.00 e-h$ & $41.67 \mathrm{ij}$ & 1.61hi & $38.50 \mathrm{c}-\mathrm{e}$ & $53.56 c$ \\
\hline \multirow[t]{4}{*}{ Binadhan-8 } & Control & $7.32 \mathrm{~h}$ & $23.20 \mathrm{~g}-\mathrm{j}$ & $77.00 \mathrm{kl}$ & $220.00 e-g$ & $12.000-r$ & $32.67 \mathrm{kl}$ & $1.95 b c$ & $25.610-q$ & $29.25 \mathrm{k}$ \\
\hline & AsA & 7.09hi & $23.36 \mathrm{~g}-\mathrm{j}$ & $82.67 \mathrm{j}-1$ & $230.00 \mathrm{ef}$ & $12.33 n-r$ & $31.67 \mathrm{kl}$ & $2.18 a$ & $26.39 n-q$ & $26.15 \mathrm{~lm}$ \\
\hline & Salt & $6.46 i$ & $22.11 \mathrm{i}-\mathrm{k}$ & 70.001 & $170.00 \mathrm{~h}-\mathrm{j}$ & $9.33 r$ & 29.331 & $1.89 \mathrm{~cd}$ & $31.48 \mathrm{i}-1$ & $48.93 d$ \\
\hline & Salt + AsA & $6.53 i$ & $23.20 \mathrm{~g}-\mathrm{j}$ & $83.00 \mathrm{j}-1$ & $190.00 f-h$ & $10.67 q r$ & $35.33 k$ & $1.96 \mathrm{bc}$ & $30.21 \mathrm{j}-\mathrm{m}$ & $38.49 f$ \\
\hline \multirow[t]{4}{*}{ Binadhan-10 } & Control & $10.64 c-e$ & $29.33 b$ & $123.33 \mathrm{~d}-\mathrm{h}$ & $376.67 b$ & $17.33 \mathrm{~g}-1$ & $58.00 \mathrm{de}$ & $2.16 a$ & $27.69 m-0$ & $32.63 \mathrm{ij}$ \\
\hline & AsA & 10.69c-e & $28.84 b$ & 133.33b-f & $386.67 b$ & $18.00 f-I$ & $61.67 \mathrm{~cd}$ & $2.17 a$ & $28.461-0$ & $30.25 \mathrm{jk}$ \\
\hline & Salt & $10.63 c-e$ & $27.58 b c$ & $101.00 \mathrm{~h}-\mathrm{k}$ & $293.33 d$ & $16.00 \mathrm{i}-\mathrm{n}$ & $49.67 \mathrm{fg}$ & $1.99 \mathrm{~b}$ & $31.60 \mathrm{~h}-1$ & $45.87 e$ \\
\hline & Salt + AsA & $10.93 b-d$ & $27.88 \mathrm{bc}$ & $120.67 d-h$ & $333.33 \mathrm{~cd}$ & $18.33 f-k$ & $57.00 \mathrm{de}$ & $1.86 \mathrm{c}-\mathrm{e}$ & $29.74 j-m$ & $37.50 \mathrm{fg}$ \\
\hline \multirow[t]{4}{*}{ BRRI dhan28 } & Control & $12.23 a$ & $26.52 \mathrm{~cd}$ & $120.00 \mathrm{~d}-\mathrm{h}$ & $303.33 d$ & $21.67 \mathrm{~d}-\mathrm{f}$ & $56.00 \mathrm{de}$ & 1.48jk & $27.61 \mathrm{~m}-0$ & 33.48hi \\
\hline & AsA & $12.17 a$ & $26.42 c-e$ & $113.33 \mathrm{e}-\mathrm{i}$ & $300.00 d$ & $21.00 \mathrm{e}-\mathrm{g}$ & $57.00 \mathrm{de}$ & $1.66 \mathrm{gh}$ & $27.23 m-p$ & $28.71 \mathrm{kl}$ \\
\hline & Salt & $10.54 c-e$ & $22.74 \mathrm{~g}-\mathrm{k}$ & $87.00 \mathrm{i}-\mathrm{k}$ & $140.00 \mathrm{j}$ & $12.33 n-r$ & $36.67 j k$ & $1.03 n$ & $43.11 \mathrm{ab}$ & $60.25 a$ \\
\hline & Salt + AsA & $11.65 a b$ & $24.15 f-i$ & $103.33 \mathrm{~g}-\mathrm{k}$ & $186.67 \mathrm{~g}-\mathrm{i}$ & 15.67j-0 & $51.33 \mathrm{f}$ & $1.27 \mathrm{~m}$ & $32.37 \mathrm{~g}-\mathrm{k}$ & $57.25 b$ \\
\hline \multirow[t]{4}{*}{ BRRI dhan67 } & Control & $11.13 \mathrm{bc}$ & $23.38 \mathrm{~g}-\mathrm{j}$ & $110.00 \mathrm{f}-\mathrm{j}$ & $246.67 \mathrm{e}$ & $14.67 k-p$ & 43.00hi & $1.66 \mathrm{gh}$ & $24.11 p q$ & $23.17 n$ \\
\hline & AsA & $11.64 a b$ & $23.27 \mathrm{~g}-\mathrm{j}$ & 100.00h-k & $230.00 \mathrm{ef}$ & $14.331-\mathrm{q}$ & $44.67 g-i$ & $1.65 \mathrm{~h}$ & $23.60 \mathrm{~g}-\mathrm{i}$ & $25.39 \mathrm{mn}$ \\
\hline & Salt & $10.06 \mathrm{ef}$ & $20.67 k$ & $76.67 \mathrm{kl}$ & $146.67 \mathrm{ij}$ & $11.67 p-r$ & $35.33 k$ & $1.41 \mathrm{kl}$ & $34.80 f-h$ & $43.37 e$ \\
\hline & Salt + AsA & $10.66 c-e$ & $21.79 \mathrm{jk}$ & 100.00h-k & $176.67 \mathrm{~h}-\mathrm{j}$ & $13.33 \mathrm{~m}-\mathrm{q}$ & $42.00 \mathrm{ij}$ & $1.52 \mathrm{ij}$ & $30.31 \mathrm{j}-\mathrm{k}$ & $35.33 \mathrm{gh}$ \\
\hline \multirow[t]{4}{*}{ BRRI dhan78 } & Control & $12.09 a$ & $24.49 d-h$ & $156.67 a-c$ & $350.00 b c$ & $19.67 \mathrm{e}-\mathrm{i}$ & $51.33 f$ & $1.78 \mathrm{e}-\mathrm{f}$ & $35.11 \mathrm{fg}$ & $23.06 n$ \\
\hline & AsA & $12.05 a$ & $24.24 \mathrm{e}-\mathrm{i}$ & 140.00a-e & $356.67 b c$ & $19.33 \mathrm{e}-\mathrm{j}$ & $52.67 \mathrm{ef}$ & $1.84 \mathrm{~d}-\mathrm{f}$ & $32.56 \mathrm{~g}-\mathrm{j}$ & $23.67 \mathrm{mn}$ \\
\hline & Salt & $10.64 c-e$ & $23.09 \mathrm{~g}-\mathrm{j}$ & $123.33 \mathrm{~d}-\mathrm{h}$ & $210.00 \mathrm{e}-\mathrm{h}$ & $16.33 \mathrm{~h}-\mathrm{m}$ & $42.00 \mathrm{ij}$ & $1.64 \mathrm{~h}$ & $40.31 b-d$ & $35.98 f-h$ \\
\hline & Salt + AsA & $11.23 \mathrm{bc}$ & $24.77 d-g$ & $143.33 a-d$ & $233.33 \mathrm{e}$ & $18.33 \mathrm{f}-\mathrm{k}$ & $48.00 f-h$ & $1.75 \mathrm{fg}$ & $37.93 d-f$ & $29.16 k$ \\
\hline
\end{tabular}

\section{Shoot Length}

On average, shoot length was the highest in FL-478 $(31.74 \mathrm{~cm})$ and lowest in Binadhan-8 $(23.20 \mathrm{~cm})$, under control conditions (Table 1). Exposure of rice seedlings to salinity caused a significant reduction in shoot length, with the greatest reduction observed for Binadhan-6 (20.24\%) followed by BRRI dhan28, FL-478, BRRI dhan67, Binadhan-10, BRRI dhan78 and Binadhan-8 (14.26, $12.35,11.59,5.97,5.72$ and $4.70 \%$, respectively), compared to controls (Table 1). AsA pre-treatment was found to increase shoot length, the greatest increase (7.45\%) was noted for Binadhan-6 followed by BRRI dhan78, BRRI dhan28, BRRI dhan67, Binadhan-8, FL-478 and Binadhan-10 (7.28, 6.20, 5.42, 4.93, 3.67 and $1.09 \%$, respectively) in comparison with the seedlings imposed to salinity without AsA pre-treatment (Table 1).

\section{Fresh Root Weight}

Under control conditions, the greatest fresh root weight was found in FL-478 (166.67 mg) and lowest in Binadhan-6 $(77.00 \mathrm{mg})$ (Table 1). A decrease in fresh root weight was observed in response to salinity; the greatest reduction was found for BRRI dhan67 (30.30\%) and least reduction was found for Binadhan-8 (9.09\%), compared to their controls. AsA pre-treatment was found to increase the root fresh weight, the greatest increase (30.43\%) was found for BRRI dhan67, followed by Binadhan-6, Binadhan-10, BRRI dhan28, Binadhan-8, BRRI dhan78 and FL-478 $(20.00,19.48,18.77,18.57,16.22$ and $15.58 \%$, respectively), in comparison with the seedlings imposed to salinity without AsA pre-treatment (Table 1).

\section{Fresh Shoot Weight}

The greatest fresh shoot weight was found for FL-478 (460.00 mg) and the lowest for Binadhan-8 (220.00 mg) (Table 1) under control conditions. In response to salinity, shoot fresh weight showed a significant decrease in all of the genotypes, with the greatest reduction for Binadhan-6 (54.74\%) and the least reduction for Binadhan-10 (22.13\%), as compared to controls. AsA pre-treatment was found to reduce the decrease of fresh root weight under the condition of salinity. The highest decrease was found in BRRI dhan28 (33.34\%) followed by Binadhan-6, BRRI dhan67, Binadhan-10, Binadhan-8, BRRI dhan78 and FL-478 $(23.26,20.45,13.64,11.76,11.11$ and $7.69 \%$, respectively) as compared to the seedlings treated with salt stress only (Table 1).

\section{Dry Root Weight}

The maximum dry root weight was observed in FL-478 (42 mg) and minimum in Binadhan- 8 (12 mg) under control treatments 
(Table 1). In response to salt stress dry root weight was found to decrease, the greatest reduction was recorded for BRRI dhan28 $(43.10 \%)$ and the least for Binadhan-10 (7.67\%). Exogenous AsA application showed to mitigate the negative impacts of salt stress and increase root dry weight. The greatest increase $(27.09 \%)$ was for BRRI dhan28 followed by Binadhan-6, Binadhan-10, Bindhan-8, BRRI dhan67, BRRI dhan78, and FL-478 (17.65, 14.56, $14.36,14.22,12.25$ and $9.32 \%$, respectively), in comparison with the seedlings imposed to salinity without pretreatment (Table 1).

\section{Dry Shoot Weight}

The highest shoot dry weight was recorded for FL-478 (72.33 mg) and the lowest for Binadhan-8 (32.67 mg) under control treatments (Table 1). Salt stress lead to a significant decrease in shoot dry weight for all the genotypes studied. The greatest reduction was observed in salt susceptible BRRI dhan28 (34.51\%) whereas the least reduction was found for Binadhan-8 (10.22\%) compare to their control. Pre-treated AsA salt stressed seedlings showed an increase in shoot dry weight, the greatest increase (39.97\%) was found in BRRI dhan28 followed by Binadhan-6, Binadhan-8, BRRI dhan67, Binadhan-10, BRRI dhan78, and FL-478 (21.38, 20.45, 18.88, 14.76, 14.29 and $5.92 \%$, respectively), in comparison with the seedlings imposed to salinity without pretreatment (Table 1).

\section{Total Chlorophyll}

The highest total chlorophyll content was found for Binadhan-10 (2.16 $\left.\mathrm{mg} \mathrm{g}^{-1} \mathrm{FW}\right)$ and the lowest in BRRI dhan28 (1.48 $\mathrm{mg} \mathrm{g}^{-1}$ FW) (Table 1) under control condition. Due to salt stress, the greatest decrease was found for BRRI dhan28 (30.41\%) and the least for Binadhan-8 (3.08\%) (Table 1). AsA pre-treated seedlings had higher total chlorophyll contents in comparison with the seedlings imposed to salinity without pretreatment. The greatest increase $(23.30 \%)$ was recorded for BRRI dhan28 followed by Binadhan-6, FL-478, BRRI dhan67, BRRI dhan78, Binadhan-10, and Binadhan-8 (21.05, 13.29, 7.80, $6.71,6.53$ and $3.7 \%$, respectively) (Table 1 ).

\section{Hydrogen Peroxide}

The highest level of $\mathrm{H}_{2} \mathrm{O}_{2}$ was found in FL-478 (35.4l nmol g-1 FW), with the lowest in BRRI dhan67 (24.11 $\left.\mathrm{mg} \mathrm{g}^{-1} \mathrm{FW}\right)$ under control conditions (Table 1). Under salinity the greatest increase in $\mathrm{H}_{2} \mathrm{O}_{2}$ was recorded in susceptible BRRI dhan28 (56.14\%) and the lowest in Binadhan-10 (14.12\%) as compared to controls. Exogenous AsA pre-treatment was found to improve salt stress tolerance by lowering $\mathrm{H}_{2} \mathrm{O}_{2}$ levels. The greatest reduction $(24.91 \%)$ in $\mathrm{H}_{2} \mathrm{O}_{2}$ was found for BRRI dhan28, followed by Binadhan-6, BRRI dhan67, BRRI dhan78, Binadhan-10, FL-478 and Binadhan-8 $(14.61,12.90,5.90,5.89,5.58$ and $4.03 \%$, respectively) as compared to plants treated with salt stress only (Table 1 ).

\section{Malondialdehyde (MDA)}

The highest level of MDA was found in in Binadhan-6 (33.74 $\mathrm{nmol} \mathrm{g}^{-1} \mathrm{FW}$ ) and the lowest in BRRI dhan78
(23.06 nmol g-1 FW) under control conditions (Table 1). A sharp increase in MDA contents in response to salinity was observed for all of the genotypes, with the highest level found in BRRI dhan28 (79.95\%) and the lowest in FL-478 (20.88\%) as compared to controls. Application of exogenous AsA under salt conditions resulted in a reduction in the MDA content with the greatest reduction was found for Binadhan-8 (21.33\%) followed by BRRI dhan78, BRRI dhan67, Binadhan-10, FL478, Binadhan-6 and BRRI dhan28 (19.12, 18.54, 18.25, 11.50 , 8.04 and $4.98 \%$, respectively) in comparison with the seedlings imposed to salinity without pretreatment (Table 1).

\section{Effect of AsA, Salt Stress and salt+2mM AsA Treatments on Rice Genotypes at the Reproductive Stage}

The result of the analysis of variance for all the characters showed highly significant $(P \leq 0.001)$ variation due to genotypes and treatments (Supp. Table 2). Days to maturity, numbers of filled grains panicle $e^{-1}$ number of unfilled grains panicle ${ }^{-1}$, spikelet fertility, 100-seed weight, grain yield panicle ${ }^{-1}, \mathrm{H}_{2} \mathrm{O}_{2}$ also showed significant $(P \leq 0.001) \mathrm{G} \times \mathrm{T}$ interactions, whereas plant height and panicle length showed no significant $\mathrm{G} \times \mathrm{T}$ interaction (Supp. Table 2).

\section{Days to Maturity}

The maximum number of days to maturity under control conditions was found for BRRI dhan78 (164), whereas the least was found for BRRI dhan67 (148) (Table 2). A significant decrease in days to maturity was observed under salinity stress in all the genotypes studied. The greatest reduction was observed in salt susceptible Binadhan-6 (11.40\%), whereas the least reduction was found for BRRI dhan78 (8.10\%) (Table 2). Exogenous AsA showed no significant influence on days to maturity $(2.27,1.47,1.39,0.97,0.96,0.74$ and $0.65 \%$ by BRRI dhan28, FL-478, Binadhan-6, Binadhan-8, Binadhan-10, BRRI dhan67, and BRRI dhan78, respectively) in comparison with the seedlings imposed to salinity without pretreatment. Exogenous AsA applied non-stressed showed no significant increases in days to maturity as compared to control (Table 2).

\section{Plant Height}

On average, plant height was the highest in Binadhan-6 $(84.15 \mathrm{~cm})$ and lowest in FL-478 $(55.39 \mathrm{~cm})$ under control conditions (Table 2). Exposure to salinity stress caused a decrease in plant height with the greatest decrease observed for BRRI dhan28 (5.82\%) followed by FL-478, Binadhan-6, BRRI dhan67, BRRI dhan78, Binadhan-8 and Binadhan-10 $(4.89,4.58 \%, 4.35,4.13,2.56$ and $2.49 \%$, respectively) compared to control. Little increase in plant height was noted in response to AsA, application however the greatest increase was found for FL-478 (3.83\%) followed by BRRI dhan28, Binadhan-6, BRRI dhan67, BRRI dhan78, Binadhan-8 and Binadhan-10 (3.73, 3.41, 2.89, 2.70, 1.44 and $0.81 \%$ respectively)in relation to the seedlings imposed to without AsA pretreatment (Table 2). 
Table 2: Effects of exogenous AsA on different morphological and biochemical traits of seven rice genotypes grown under salt stress condition at the reproductive stage. Data are presented with mean values of four independent replicates. Different letters in the same column indicate significant differences between the treatments at $p<0.05$ level using the Tukey's multiple comparison tests. Control (water), AsA (2mM AsA as foliar spray), Salt (10.0 dSm $\mathrm{din}^{-1}$ in water); Salt+AsA (10.0 dSm-1 $+2 \mathrm{mM} \mathrm{AsA)}$

\begin{tabular}{|c|c|c|c|c|c|c|c|c|c|c|}
\hline $\begin{array}{l}\text { Genotype } \times \\
\text { Treatment }\end{array}$ & & $\begin{array}{l}\text { Days to } \\
\text { maturity }\end{array}$ & $\begin{array}{l}\text { Plant height } \\
\text { (cm) }\end{array}$ & $\begin{array}{l}\text { Panicle } \\
\text { length } \\
\text { (cm) } \\
\end{array}$ & $\begin{array}{l}\text { Number of filled } \\
\text { grains panicle }{ }^{-1}\end{array}$ & $\begin{array}{c}\text { Number of } \\
\text { unfilled grains } \\
\text { panicle }{ }^{-1}\end{array}$ & $\begin{array}{c}\text { Spikelet } \\
\text { fertility } \\
(\%)\end{array}$ & $\begin{array}{l}\text { 100-seed } \\
\text { weight } \\
\text { (g) }\end{array}$ & $\begin{array}{l}\text { Grain yield } \\
\text { panicle }^{-1}(g)\end{array}$ & $\begin{array}{c}\mathrm{H}_{2} \mathrm{O}_{2} \\
\left(\mathrm{nmol} \mathrm{g}^{-1} \mathrm{FW}\right)\end{array}$ \\
\hline \multirow[t]{4}{*}{ FL-478 } & Control & $150.00 \mathrm{e}-\mathrm{g}$ & $55.39 \mathrm{~m}$ & 19.76h-j & $61.28 \mathrm{~g}$ & $27.08 \mathrm{~h}-\mathrm{j}$ & $69.35 b$ & $2.56 a$ & $1.61 \mathrm{e}$ & $33.76 h-j$ \\
\hline & AsA & $150.00 \mathrm{e}-\mathrm{g}$ & $55.83 m$ & $19.77 \mathrm{~g}-\mathrm{j}$ & $62.74 \mathrm{~g}$ & $27.6 \mathrm{lh}-\mathrm{j}$ & $69.50 b$ & $2.50 a$ & $1.66 \mathrm{e}$ & 33.70h-j \\
\hline & Salt & $136.00 \mathrm{kl}$ & $52.68 m$ & 18.61j & 13.241 & $75.63 \mathrm{ab}$ & $14.99 j$ & 1.58hi & 0.211 & $43.32 \mathrm{a}$ \\
\hline & Salt + AsA & $138.00 \mathrm{j}-1$ & $54.70 \mathrm{~m}$ & $19.23 \mathrm{ij}$ & 19.761 & $69.42 a-c$ & $22.19 i$ & $1.92 \mathrm{f}$ & 0.351 & $39.33 b-d$ \\
\hline \multirow[t]{4}{*}{ Binadhan-6 } & Control & $161.00 \mathrm{~b}$ & $84.15 a$ & $23.13 b c$ & $109.37 a$ & $21.29 \mathrm{ij}$ & $83.72 a$ & $2.26 b-d$ & $2.50 a$ & $31.74 \mathrm{ij}$ \\
\hline & AsA & 162.00ab & $84.00 a b$ & $23.24 b$ & $106.31 \mathrm{ab}$ & $20.92 \mathrm{ij}$ & $83.55 a$ & $2.29 b c$ & $2.48 a$ & $31.72 \mathrm{ij}$ \\
\hline & Salt & $144.00 \mathrm{i}$ & $80.30 c-e$ & $21.82 b-e$ & $50.29 h-j$ & $80.16 a$ & $38.61 \mathrm{gh}$ & 1.231 & $0.77 \mathrm{~h}-\mathrm{j}$ & $42.66 a b$ \\
\hline & Salt + AsA & 146.00hi & $83.04 a-c$ & $22.53 b-d$ & $60.66 \mathrm{gh}$ & $70.87 a-c$ & $46.18 d-f$ & $1.40 \mathrm{jk}$ & $0.85 f-h$ & $34.54 f-j$ \\
\hline \multirow[t]{4}{*}{ Binadhan-8 } & Control & $150.67 \mathrm{ef}$ & $67.50 \mathrm{ij}$ & $22.50 b-d$ & $90.14 c-f$ & $15.92 \mathrm{j}$ & $84.98 a$ & $2.57 a$ & $2.20 b$ & $35.71 \mathrm{e}-\mathrm{h}$ \\
\hline & AsA & $151.67 \mathrm{de}$ & $68.10 \mathrm{i}$ & $22.42 b-e$ & $94.78 c-e$ & $16.81 \mathrm{j}$ & $84.94 a$ & $2.57 a$ & $2.13 b c$ & $35.65 \mathrm{e}-\mathrm{h}$ \\
\hline & Salt & $137.67 \mathrm{j}-1$ & $65.77 \mathrm{i}-\mathrm{k}$ & $21.73 b-f$ & $50.33 \mathrm{~h}-\mathrm{j}$ & $55.28 \mathrm{de}$ & $47.65 \mathrm{de}$ & $1.63 \mathrm{gh}$ & $0.77 \mathrm{~g}-\mathrm{i}$ & $39.45 b-d$ \\
\hline & Salt + AsA & 139.00jk & $66.72 \mathrm{ij}$ & $22.35 b-e$ & $53.51 \mathrm{~g}-\mathrm{j}$ & $53.58 \mathrm{ef}$ & $49.99 d$ & $1.69 \mathrm{gh}$ & $0.81 \mathrm{f}-\mathrm{i}$ & $38.91 \mathrm{c}-\mathrm{e}$ \\
\hline \multirow[t]{4}{*}{ Binadhan- 10} & Control & $154.00 \mathrm{~cd}$ & $77.59 \mathrm{e}-\mathrm{g}$ & $22.88 b-d$ & $85.45 \mathrm{ef}$ & $17.88 \mathrm{j}$ & $82.68 a$ & $2.37 b$ & $1.94 d$ & $34.62 f-j$ \\
\hline & AsA & $154.00 \mathrm{~cd}$ & $77.53 \mathrm{e}-\mathrm{g}$ & $22.50 \mathrm{~b}-\mathrm{d}$ & $83.04 f$ & $17.53 \mathrm{j}$ & $82.54 a$ & $2.37 b$ & $1.95 d$ & $34.70 f-i$ \\
\hline & Salt & 138.00j-I & $75.66 f-h$ & $22.14 b-e$ & $59.26 \mathrm{gh}$ & $40.82 \mathrm{fg}$ & $59.21 c$ & $1.65 \mathrm{gh}$ & $0.93 \mathrm{fg}$ & $36.42 \mathrm{~d}-\mathrm{h}$ \\
\hline & Salt + AsA & $139.33 j$ & $76.27 \mathrm{fg}$ & $22.72 b-d$ & $62.14 \mathrm{~g}$ & $38.09 \mathrm{gh}$ & $62.05 c$ & $1.75 \mathrm{~g}$ & $0.94 f$ & 33.18h-j \\
\hline \multirow[t]{4}{*}{ BRRI dhan28 } & Control & $149.00 \mathrm{e}-\mathrm{h}$ & 64.58jk & $22.08 b-e$ & $91.51 c-f$ & $14.84 j$ & $86.10 a$ & $2.27 b-d$ & $2.02 \mathrm{~cd}$ & $31.28 \mathrm{j}$ \\
\hline & AsA & $150.00 \mathrm{e}-\mathrm{g}$ & $64.21 \mathrm{jk}$ & $21.42 \mathrm{c}-\mathrm{h}$ & $89.32 d-f$ & $16.87 j$ & $84.14 a$ & $2.29 b c$ & $2.03 \mathrm{~cd}$ & $31.29 j$ \\
\hline & Salt & $132.00 \mathrm{~m}$ & 60.821 & $20.03 f-j$ & $38.88 \mathrm{k}$ & $67.10 b-d$ & $36.65 \mathrm{~h}$ & $1.34 \mathrm{kl}$ & $0.51 \mathrm{k}$ & $41.56 a-c$ \\
\hline & Salt + AsA & $135.001 \mathrm{~m}$ & $63.09 \mathrm{kl}$ & $21.50 \mathrm{c}-\mathrm{g}$ & 45.98jk & $59.98 c-e$ & $44.30 \mathrm{~d}-\mathrm{g}$ & $1.50 \mathrm{ij}$ & $0.61 j k$ & $35.45 f-h$ \\
\hline \multirow[t]{4}{*}{ BRRI dhan67 } & Control & $148.00 f-h$ & $76.09 f-h$ & $21.93 b-e$ & $98.78 b-d$ & $15.58 \mathrm{j}$ & $86.39 a$ & $2.18 c-e$ & $2.08 b-d$ & $33.85 \mathrm{~h}-\mathrm{j}$ \\
\hline & AsA & $147.00 \mathrm{~g}-\mathrm{i}$ & $76.06 f-h$ & $21.67 b-f$ & $97.35 b-d$ & $16.26 j$ & $85.68 a$ & $2.16 \mathrm{de}$ & $2.04 \mathrm{~cd}$ & $33.82 \mathrm{~h}-\mathrm{j}$ \\
\hline & Salt & $136.00 \mathrm{kl}$ & $72.78 \mathrm{~h}$ & $20.74 \mathrm{e}-\mathrm{i}$ & 45.50jk & $68.54 a-c$ & 39.91f-h & $1.34 \mathrm{kl}$ & $0.66 \mathrm{i}-\mathrm{k}$ & $41.32 \mathrm{a}-\mathrm{c}$ \\
\hline & Salt + AsA & $137.00 \mathrm{j}-1$ & $74.88 \mathrm{gh}$ & $21.38 d-h$ & $48.27 \mathrm{i}-\mathrm{k}$ & $65.75 b-e$ & $42.32 \mathrm{e}-\mathrm{h}$ & $1.51 \mathrm{ij}$ & $0.70 h-j$ & $35.25 f-h$ \\
\hline \multirow[t]{4}{*}{ BRRI dhan78 } & Control & $164.00 \mathrm{ab}$ & $82.00 a-d$ & $26.23 a$ & $96.02 b-d$ & $31.82 \mathrm{~g}-\mathrm{i}$ & $75.19 b$ & $2.07 e$ & $1.99 \mathrm{~cd}$ & $34.18 \mathrm{~g}-\mathrm{j}$ \\
\hline & AsA & $165.00 \mathrm{a}$ & $82.28 a-c$ & $26.26 a$ & $99.75 a-c$ & $33.68 \mathrm{~g}-\mathrm{i}$ & $74.79 b$ & $2.12 \mathrm{e}$ & $2.01 \mathrm{~cd}$ & $34.19 \mathrm{~g}-\mathrm{j}$ \\
\hline & Salt & $154.00 \mathrm{~cd}$ & $78.61 d-f$ & $25.10 a$ & $54.81 \mathrm{~g}-\mathrm{j}$ & 73.64ab & $42.65 \mathrm{e}-\mathrm{h}$ & $1.41 j \mathrm{k}$ & $0.81 f-i$ & $37.85 d-f$ \\
\hline & Salt + AsA & $155.00 \mathrm{c}$ & $80.73 b-e$ & $25.73 a$ & $56.85 \mathrm{~g}-\mathrm{i}$ & $71.75 a-c$ & $44.23 \mathrm{~d}-\mathrm{g}$ & $1.51 \mathrm{ij}$ & $0.85 \mathrm{f}-\mathrm{h}$ & $37.35 \mathrm{~d}-\mathrm{g}$ \\
\hline
\end{tabular}

\section{Panicle Length}

The highest panicle length was found for BRRI dhan78 (26.23) and least for FL-478 (19.76) under control conditions (Table 2). Salt stress resulted in a decrease in panicle length for all genotypes with the greatest reduction for BRRI dhan28 (9.28\%) and least reduction for Binadhan-10 (3.23\%) compared to control conditions. Exogenous AsA application under salt stress was found to increase panicle length, with the greatest increase for BRRI dhan 28 (6.86\%) followed by FL-478, Binadhan-6, BRRI dhan67, Binadhan- 8 , Binadhan- 10 and BRRI dhan $78(3.33,3.25$, $3.09,2.85,2.62$ and $2.51 \%$, respectively) as compared to the plants treated with salt treatment only (Table 2). AsA treated non-stressed genotypes showed no significant differences in panicle length in comparison with controls.

\section{Number of Filled Grains Panicle ${ }^{-1}$}

The highest number of filled grains panicle ${ }^{-1}$ was found for Binadhan-6 (109.37) under control conditions and the lowest was for FL-478 (62.74) (Table 2). Imposition of salinity resulted in a significant decrease in the number of filled grains panicle ${ }^{-1}$ among all of the genotypes with the greatest reduction found for FL-478 (78.39\%) followed by BRRI dhan28, Binadhan-6, BRRI dhan67, Binadhan-8, BRRI dhan 78 and Binadhan-10 (57.51, 54.02, 53.94, $44.16,42.92$ and $30.65 \%$, respectively) as compared to controls.
Application of exogenous AsA under salt stress was increased the number of filled grains panicle ${ }^{-1}$ as compared to the plants treated with salt stress only. The greatest increase was found for FL-478 (49.24\%) followed by Binadhan-6, BRRI dhan28, Binadhan-8, BRRI dhan67, Binadhan-10 and BRRI dhan78 (20.62, 18.26, $6.32,6.09,4.86$ and $3.72 \%$, respectively). AsA treated non-stressed genotypes showed no significant differences in the number of filled grains panicle ${ }^{-1}$ in comparison with controls (Table 2).

\section{Number of Unfilled Grains Panicle ${ }^{-1}$}

The maximum number of unfilled grains panicle ${ }^{-1}$ was observed for BRRI dhan78 (31.82) and minimum for BRRI dhan 28 (14.84) under control treatments (Table 2). The number of unfilled grains panicle ${ }^{-1}$ showed a significant decrease in response to salinity, with the greatest recorded for BRRI dhan28 (352.14\%) followed by BRRI dhan67, Binadhan-6, Bindhan-8, FL-478, BRRI dhan78 and Binadhan-10 (339.92, 276.51, $247.24,179.28,131.42$ and $128.30 \%$, respectively). Exogenous AsA application was found to mitigate the negative impacts of salt stress by reducing the number of unfilled grains panicle ${ }^{-1}$. The greatest reduction was found for Binadhan-6 (11.58\%) followed by BRRI dhan28, FL-478, Bindhan-10, BRRI dhan67, Binadhan- 8 and BRRI dhan78 $(10.61,8.21,6.69,4.07,3.07$ and $2.57 \%$, respectively) as compared to plants treated with salt stress only (Table 2). 


\section{Spikelet Fertility (\%)}

Imposition of salinity showed a substantial decrease in the percentage spikelet fertility for all of the genotypes compared to controls. The highest percentage of spikelet fertility was found for BRRI dhan67 (86.39\%) under control condition whereas the lowest for FL-478 (69.35\%) (Table 2). Due to salt stress, the greatest reduction in percentage spikelet fertility was found for FL-478 (78.38\%) and the least for Binadhan-10 $(28.39 \%)$. The salt $+2 \mathrm{mM}$ AsA treatment was found to increase the percentage fertility as compared to the plants treated with salt stress only. The greatest increase was recorded for FL-478 (48.03\%) followed by BRRI dhan28, Binadhan-6, BRRI dhan67, Binadhan-8, Binadhan-10 and BRRI dhan $78(20.87,19.60,6.04$, $4.91,4.80$ and $3.0 \%$, respectively) (Table 2).

\section{0-seed Weight}

The highest 100-seed weight was recorded for Binadhan-8 (2.57g) and the lowest in BRRI dhan78 (2.07g) under control treatments (Table 2). Salt stress resulted in a meaningful decrease in 100seed weight for all of the genotypes studied in comparison with controls. The greatest reduction was observed in salt susceptible Binadhan-6 (45.58\%) followed by BRRI dhan28, BRRI dhan67, FL-478, Binadhan-8, BRRI dhan78 and Binadhan-10 (40.97, $38.53,38.28,36.58,31.88$ and $30.38 \%$, respectively). AsA treated salt-stressed plants showed an increase in 100-seed weight in comparison with plants subjected to salt stress without AsA application. The greatest increased was found for FL-478 (21.52\%) followed by Binadhan-6, BRRI dhan67, BRRI dhan28, BRRI dhan78, Binadhan-10 and Binadhan-8 $(13.82,12.69,11.94$, 7.09, 6.06 and $3.68 \%$, respectively) (Table 2 ).

\section{Grain Yield Panicle ${ }^{-1}$}

Grain yield panicle ${ }^{-1}$ was a maximum for Binadhan-6 $(2.50 \mathrm{~g})$ and minimum for FL-478 (1.61 g) under control conditions (Table 2). Grain yield panicle ${ }^{-1}$ showed a significant decrease in response to salinity in all of the genotypes with the greatest decrease for FL-478 (86.96\%), followed by BRRI dhan28, Binadhan-6, BRRI dhan67, Binadhan-8, BRRI dhan78 and Binadhan-10 (74.75, $69.20,68.27,65.00,59.30$ and $52.06 \%$, respectively) related to control. Application of exogenous AsA under the condition of salinity stress was found to mitigate the negative impact of salt stress, with an increased grain yield panicle ${ }^{-1}$ in relation with the seedlings imposed to salt stress only. The greatest increase was found for FL-478 (66.67\%) followed by BRRI dhan28, Binadhan-6, BRRI dhan67, Binadhan- 8 , BRRI dhan78, and Binadhan- 10 $(19.61,10.39,6.06,5.19,4.94$ and $1.08 \%$, respectively) (Table 2).

\section{Hydrogen Peroxide}

The highest $\mathrm{H}_{2} \mathrm{O}_{2}$ level was found in Binadhan- 8 ( $35.71 \mathrm{nmolg}^{-1} \mathrm{FW}$ ) whereas lowest was in BRRI dhan28 (31.28 nmol g-1 $\mathrm{FW}$ ) under control conditions (Table 2). In response to salt stress, $\mathrm{H}_{2} \mathrm{O}_{2}$ levels showed a significant increase in comparison with controls. The highest levels was found in susceptible Binadhan-6 (34.40\%) followed by BRRI dhan28, FL-478, BRRI dhan67, BRRI dhan78, Binadhan-8 and Binadhan-10 (32.86, 28.32, 22.07, 10.74, 10.47 and $5.20 \%$, respectively). Application of AsA under salt stress conditions reversed the negative effects of salt stress by decreasing the $\mathrm{H}_{2} \mathrm{O}_{2}$ levels in comparison with the plants subjected to salinity without AsA. The greatest reduction in $\mathrm{H}_{2} \mathrm{O}_{2}$ levels was found for Binadhan-6 (19.03\%), followed by BRRI dhan28, BRRI dhan67, FL-478, Binadhan-10, Binadhan-8 and BRRI dhan78 (14.70, $14.69,9.21,8.90,1.37$ and $1.32 \%$ respectively) (Table 2 ).

\section{Estimation of Correlation Co-efficient Among Nine Characters of Rice Genotypes Under Control and Salt Stress Conditions at the Reproductive Stage}

Days to maturity showed a significant positive correction with plant height and panicle length under both control and salt stress conditions, but showed significant positive correlation with number of filled and unfilled grains panicle- ${ }^{1}$ and negative correlation with 100-seed weight and $\mathrm{H}_{2} \mathrm{O}_{2}$ content under control conditions. Days to maturity showed a significant positive correction with grain yield panicle $\mathrm{e}^{-1}$ under stress conditions (Table 3). Plant height showed a significant positive correlation with panicle length and number of filled grains panicle ${ }^{-1}$ and grain yield panicle ${ }^{-1}$ under both control and salt stress conditions, but a significant negative correlation with 100-seed weight under control conditions. Plant height showed a significant positive correction with grain yield panicle-1 and negative correlation with $\mathrm{H}_{2} \mathrm{O}_{2}$ (Table 3). Panicle length showed a significant positive correction with number of filled grains panicle ${ }^{-1}$ under both control and salt stress conditions, but a significant negative correlation with 100seed weight under control conditions. Under salt stress conditions, panicle length showed a significant positive correlation with spikelet fertility and grain yield panicle ${ }^{-1}$, but showed a significant negative correlation with 100-seed weight and $\mathrm{H}_{2} \mathrm{O}_{2}$ content. Number of filled grains panicle-1 showed a significant positive correlation with spikelet fertility and grain yield panicle ${ }^{-1}$ under both control and stress conditions, but showed significant negative correlation with 100-seed weight under control conditions. Under salt stress conditions number of filled grains panicle ${ }^{-1}$ showed a significant negative correlation with number unfilled grains panicle $^{-1}$ and $\mathrm{H}_{2} \mathrm{O}_{2}$ content. Number of unfilled grains panicle ${ }^{-1}$ showed a significant negative correlation with spikelet fertility under both control and stress conditions, but showed significant negative correlation with grain yield plant ${ }^{-1}$ and $\mathrm{H}_{2} \mathrm{O}_{2}$ under stress condition. Spikelet fertility showed a significant positive correlation with grain yield panicle ${ }^{-1}$ and negative correlation with $\mathrm{H}_{2} \mathrm{O}_{2}$ under salt stress conditions. 100-seed weight and grain yield panicle ${ }^{-1}$ showed a significant negative correlation with $\mathrm{H}_{2} \mathrm{O}_{2}$ under salt stress conditions (Table 3).

\section{Principal Components (PCs) for Nine Morphological and Biochemical Traits in Seven Rice Genotypes from PCA}

The first two principal components $\mathrm{PCl}$ and $\mathrm{PC} 2$ explained 66.5\% and $20.5 \%$ of total variation, respectively (Table 4 ). Because PCl collectively explained more than half $(66.5 \%)$ of the variation and contributed more to the separation of genotypes into different categories, they were used to classify the 84 groups of 7 rice genotypes into four major groups including highly salt sensitive, moderately salt sensitive, moderately salt tolerant and highly 
Table 3: Phenotypic correlation co-efficient among nine characters of rice genotypes grown under control and salt stress condition at the reproductive stage

\begin{tabular}{|c|c|c|c|c|c|c|c|c|c|}
\hline Traits & & $\begin{array}{l}\text { Days to } \\
\text { maturity }\end{array}$ & Plant height & $\begin{array}{l}\text { Panicle } \\
\text { length }\end{array}$ & $\begin{array}{l}\text { Number of filled } \\
\text { grains panicle }{ }^{-1}\end{array}$ & $\begin{array}{l}\text { Number of unfilled } \\
\text { grains panicle-1 }\end{array}$ & $\begin{array}{l}\text { Spikelet } \\
\text { fertility }\end{array}$ & $\begin{array}{c}\text { 100-seed } \\
\text { weight }\end{array}$ & $\begin{array}{c}\text { Grain yield } \\
\text { panicle }^{-1}\end{array}$ \\
\hline Plant height & $\begin{array}{l}\mathrm{C} \\
\mathrm{S}\end{array}$ & $\begin{array}{l}0.708 * * * \\
0.651 * *\end{array}$ & & & & & & & \\
\hline Panicle length & $\begin{array}{l}\mathrm{C} \\
\mathrm{S}\end{array}$ & $\begin{array}{l}0.792^{* * *} \\
0.850 * * *\end{array}$ & $\begin{array}{l}0.753 * * * \\
0.786 * * *\end{array}$ & & & & & & \\
\hline $\begin{array}{l}\text { Number of filled grains } \\
\text { panicle }{ }^{-1}\end{array}$ & $\begin{array}{l}\mathrm{C} \\
\mathrm{S}\end{array}$ & $\begin{array}{c}0.438^{*} \\
0.431\end{array}$ & $\begin{array}{l}0.796 * * * \\
0.847 * * *\end{array}$ & $\begin{array}{l}0.597 * * \\
0.771 * * *\end{array}$ & & & & & \\
\hline $\begin{array}{l}\text { Number of unfilled grains } \\
\text { panicle }^{-1}\end{array}$ & $\begin{array}{l}\mathrm{C} \\
\mathrm{S}\end{array}$ & $\begin{array}{c}0.630 * * \\
0.262\end{array}$ & $\begin{array}{c}0.111 \\
-0.322\end{array}$ & $\begin{array}{r}0.386 \\
-0.192\end{array}$ & $\begin{array}{l}-0.246 \\
-0.618 * *\end{array}$ & & & & \\
\hline Spikelet fertility & $\begin{array}{l}\mathrm{C} \\
\mathrm{S}\end{array}$ & $\begin{array}{l}0-.258 \\
0.061\end{array}$ & $\begin{array}{c}0.324 \\
0.636 * *\end{array}$ & $\begin{array}{l}0.061 \\
0.501^{*}\end{array}$ & $\begin{array}{l}0.671 * * \\
0.879 * * *\end{array}$ & $\begin{array}{l}-0.872 * * * \\
-0.911 * * *\end{array}$ & & & \\
\hline 100-seed weight & $\begin{array}{l}\mathrm{C} \\
\mathrm{S}\end{array}$ & $\begin{array}{l}-0.501^{*} \\
-0.188\end{array}$ & $\begin{array}{l}-0.686 * * \\
-0.360\end{array}$ & $\begin{array}{l}-0.652 * * \\
-0.053\end{array}$ & $\begin{array}{l}-0.641^{* *} \\
-0.062\end{array}$ & $\begin{array}{c}-0.202 \\
0.317\end{array}$ & $\begin{array}{c}-0.180 \\
0.179\end{array}$ & & \\
\hline Grain yield panicle $e^{-1}$ & $\begin{array}{l}\mathrm{C} \\
\mathrm{S}\end{array}$ & $\begin{array}{l}0.364 \\
0.455^{*}\end{array}$ & $\begin{array}{l}0.663 * * \\
0.864 * * *\end{array}$ & $\begin{array}{c}0.398 \\
0.779 * * *\end{array}$ & $\begin{array}{l}0.862 * * * \\
0.973 * * *\end{array}$ & $\begin{array}{l}-0.277 \\
-0.609 * *\end{array}$ & $\begin{array}{c}0.620 \\
0.870 * * *\end{array}$ & $\begin{array}{c}-0.282 \\
0.015\end{array}$ & \\
\hline $\mathrm{H}_{2} \mathrm{O}_{2}$ & $\begin{array}{l}\mathrm{C} \\
\mathrm{S}\end{array}$ & $\begin{array}{l}-0.076 * \\
-0.351\end{array}$ & $\begin{array}{l}-0.056 \\
-0.453 *\end{array}$ & $\begin{array}{c}0.022 \\
-0.666 * * *\end{array}$ & $\begin{array}{c}-0.314 \\
-0.673 * * *\end{array}$ & $\begin{array}{c}0.062 \\
0.563 * *\end{array}$ & $\begin{array}{c}-0.160 \\
-0.696 * * *\end{array}$ & $\begin{array}{c}0.319 \\
-0.462^{*}\end{array}$ & $\begin{array}{c}-0.256 \\
-0.695^{* * *}\end{array}$ \\
\hline
\end{tabular}

$* * *, * *$ and $*$ indicates significant at $0.1 \%, 1 \%$ and $5 \%$ level of probability respectively. Here, 'C' indicates control condition and 'S' indicates salinity stress condition.

Table 4: Principal components (PCs) for nine morphological and biochemical traits in seven rice genotypes from principal component analysis (PCA)

\begin{tabular}{|c|c|c|}
\hline Variable & $\mathrm{PCl}$ & PC2 \\
\hline Days to maturity & 0.332 & 0.243 \\
\hline Plant height & 0.188 & 0.594 \\
\hline Panicle length & 0.206 & 0.581 \\
\hline Number of filled grains panicle ${ }^{-1}$ & 0.396 & 0.063 \\
\hline Number of unfilled grains panicle ${ }^{-1}$ & -0.358 & 0.251 \\
\hline Spikelet fertility (\%) & 0.390 & -0.143 \\
\hline 100-seed weight & 0.321 & -0.383 \\
\hline Grain yield panicle ${ }^{-1}$ & 0.396 & -0.095 \\
\hline $\mathrm{H}_{2} \mathrm{O}_{2}$ & -0.339 & 0.090 \\
\hline$\%$ variation explained & $66.5 \%$ & $20.5 \%$ \\
\hline
\end{tabular}

salt tolerant. From the biplot, it was found that the PCl scores of FL-478 under the salt stress treatment completely separated from those of Binadhan- 6 under control and AsA treatments. The variation between FL-478 under control conditions and Binadhan-6 under control and AsA treatments were due to a higher negative coefficient of the traits: number of unfilled grains panicle ${ }^{-1}$ (UFG/P) and $\mathrm{H}_{2} \mathrm{O}_{2}$ compared to the positive coefficients of the traits of number of filled grains panicle $e^{-1}$, grain yield panicle ${ }^{-1}$ and spikelet fertility (Figure 1). Similarly, PC2 scores of BRRI dhan78 under Salt $+2 \mathrm{mM}$ AsA treatment completely separated from those of FL-478 control and AsA treatments, due to higher positive coefficients of the traits of plant height, panicle length, number of unfilled grains panicle ${ }^{-1}, \mathrm{H}_{2} \mathrm{O}_{2}$, days to maturity compared to the negative coefficients of the traits of 100-seed weight.

\section{Estimation of Stress Tolerance Indices Based on Grain Yield Panicle ${ }^{-1}$ Obtained from Control and Salt Stress Conditions}

The highest SSI was recorded for the genotype FL-478 (1.26) followed by BRRI dhan28 (1.09), Binadhan-6 (1.01), BRRI dhan67 (0.99), Binadhan-8 (0.95), BRRI dhan78 (0.86), Binadhan-10 (0.76). The highest value of TOL was recorded in Binadhan-6

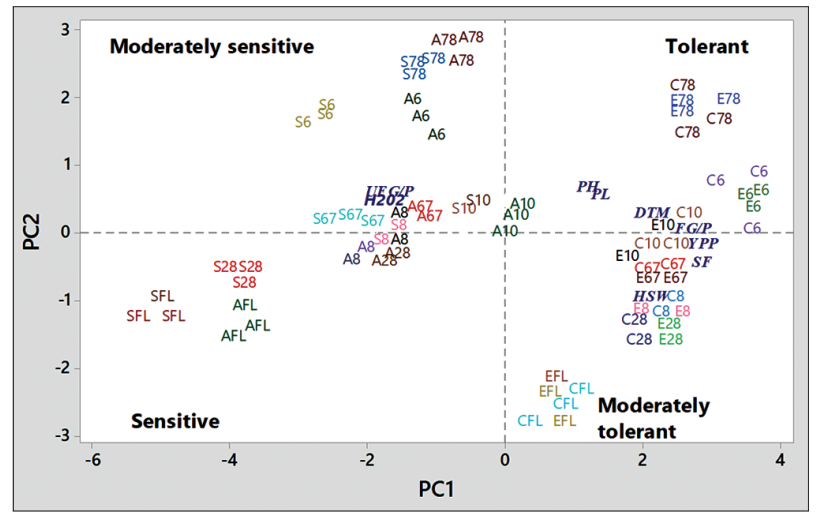

Figure 1: Biplot from the principal component analysis of the morphological and biochemical traits of seven rice genotypes under control, 2mMAsA, Salt, Salt+2mM AsA treatments. Here, DTM= Days to maturity, $\mathrm{PH}=$ Plant height, $\mathrm{PL}=$ Panicle length, $\mathrm{FG} / \mathrm{P}=$ Number of filled grains panicle-1, UFG/P= Number of unfilled grains panicle-1, $\mathrm{SF}=$ Spikelet fertility (\%), HSW=100-seed weight, $\mathrm{YPP}=\mathrm{Grain}$ yield panicle-1, $\mathrm{H}_{2} \mathrm{O}_{2}=$ Hydrogen peroxide. 'C', ' $E$ ', 'S', 'A' before number indicates treatment under control, AsA, salt, salt+2mM AsA and FL, 6, $8,10,28,67,78$ indicates genotypes FL-478, Binadhan-6, Binadhan-8, Binadhan-10, BRRI dhan28, BRRI dhan67, BRRI dhan78 respectively

(1.73) followed by BRRI dhan28 (1.51), Binadhan-8(1.44), BRRI dhan67 (1.42), FL-478 (1.4), BRRI dhan78 (1.18), Binadhan-10 (1.01) (Table 5). Maximum STI was obtained from the genotype Binadhan-10 (0.43) followed by Binadhan-8 (0.40), BRRI dhan78 (0.38), Binadhan-6 (0.36), BRRI dhan67 (0.33), BRRI dhan28 (0.25), and FL-478 (0.08). The highest YSI was obtained for the genotype Binadhan-10 (.48) followed by BRRI dhan78 (0.41), Binadhan-8 (0.35), BRRI dhan67 (0.32), Binadhan-6 (0.30), BRRI dhan28 (0.25), and FL-478 (0.13) (Table 5).

\section{Ranking based on Morphological and Biochemical Traits of Rice Genotypes at the Seedling and Reproductive Stages}

Considering all the traits at the seedling stage under control conditions, FL-478 was in first position followed by 
Table 5: Stress tolerance indices in rice genotypes, estimated from grain yield panicle $\mathrm{e}^{-1}$ obtained from control and salt stress conditions

\begin{tabular}{lcccc}
\hline Genotype & SSI & TOL & STI & YSI \\
\hline FL-478 & 1.26 & 1.4 & 0.08 & 0.13 \\
Binadhan-6 & 1.01 & 1.73 & 0.36 & 0.30 \\
Binadhan-8 & 0.95 & 1.44 & 0.40 & 0.35 \\
Binadhan-10 & 0.76 & 1.01 & 0.43 & 0.48 \\
BRRI dhan28 & 1.09 & 1.51 & 0.25 & 0.25 \\
BRRI dhan67 & 0.99 & 1.42 & 0.33 & 0.32 \\
BRRI dhan78 & 0.86 & 1.18 & 0.38 & 0.41 \\
\hline
\end{tabular}

Here, SSI: Stress susceptibility index; TOL: Tolerance index; STI: Stress tolerance index; YSI: Yield stability index.

Binadhan-10, BRRI dhan78, BRRI dhan28, Binadhan-6, BRRI dhan67, Binadhan-8. The genotype FL-478 secured the first position followed by Binadhan-10, BRRI dhan78, BRRI dhan67, Binadhan-8, BRRI dhan28, Binadhan-6 under the condition of salt stress (Supp. table 3). At the reproductive stage, Binadhan-10 was in the first position followed by Binadhan-8, Binadhan-6, BRRI dhan67, BRRI dhan78, BRRI dhan28, FL-478 under control conditions, whereas under salt stress condition, Binadhan-10 was in the first position followed by BRRI dhan78, Binadhan-8, BRRI dhan67, Binadhan-6, FL-478, BRRI dhan28 (Supp. Table 3).

\section{DISCUSSION}

Rice is currently registered as the most salt-sensitive cereal crop with a threshold of $3 \mathrm{dSm}^{-1}$ for most cultivated varieties [43]. Salinity caused a substantial reduction in plant development and growth as compared to respective control plants during all growth stages and it prevented plants from fully expressing their full genetic potential [44]. Salt stress triggers a reduction in intra-cellular water potential and water availability and so roots fail to absorb sufficient water and nutrients for adequate plant growth [45]. The current study showed that the imposition of salt stress significantly reduced the shoot growth and root characteristics and as well as leaf chlorophyll content (Table l). The reduction of shoot and root growth and chlorophyll content was greatest in the sensitive cultivars compared to tolerant genotypes. Salinity reduced growth of plants obviously due to the negative consequence of salt stress that restricts cell division [46] and arrests plant growth at least in part due to the initiation of oxidative stress [47]. Additionally, the reduction in development and growth of salt-stressed seedlings could be due to the negative effects of the high osmotic potential of the nutrient solution that lowered uptake of water and nutrients [48]. The reduction in morphological parameters and chlorophyll content due to salinity was also found by other researchers [36, 49-52]. The findings of the present experiment also show that the salt treatment led to increased $\mathrm{H}_{2} \mathrm{O}_{2}$ and MDA contents in all of the genotypes tested, but that the accumulations of $\mathrm{H}_{2} \mathrm{O}_{2}$ and MDA were lower in salt-tolerant genotypes compared to salt-sensitive genotypes (Table 1). The lower accumulation of MDA and $\mathrm{H}_{2} \mathrm{O}_{2}$ in the salttolerant genotypes implies greater protection against oxidative damage by better regulating mechanism to ROS formation to perform their signaling function $[53,54]$ and therefore, these genotypes displayed more salinity tolerance $[23,55,56]$. In contrast, the higher accumulation of $\mathrm{H}_{2} \mathrm{O}_{2}$ and MDA contents in salt-sensitive genotypes was probably due to higher rates of ROS production as well as inactivation of antioxidant enzymes [57], leading to oxidative stress and membrane lipid damage [58,59]. Generation of oxidative stress in response to short term salt stress in rice was also reported by others $[13,60]$. Importantly, an exogenous AsA pre-treatment resulted in greater root and shoot length as well as chlorophyll content for plants of all the genotypes tested, compared to plants treated with the salt stress only (Figure 2). Similar results were also indicated by other researchers [49, 61-64]. Exogenous AsA led to a reduction in ROS and MDA content, however the greatest reduction was noted in the sensitive genotypes in comparison with tolerant genotypes that could mean that the tolerant genotypes synthesize more AsA in comparison with sensitive genotype or produces lower ROS levels. Therefore, the higher growth rates of AsA pre-treated seedlings might due to efficient ROS detoxification and /or lower ROS synthesis and accumulation, and also better ion homeostasis, particularly the maintenance of low $\mathrm{Na}^{+} / \mathrm{K}^{+}$ions through the mechanisms like salt exclusion, ion partitioning and compartmentation of $\mathrm{Na}^{+}$into shoots [61] and the proper signaling function of AsA and ROS for up-regulation of stress responsive genes [65-67] (Figure 3). Significant variations in days to maturity due to treatments within a particular genotype were found because of direct salt inclusion from root zone to panicle. Salt stress forced the plants to mature earlier, but tolerant genotypes showed a similar number of days to maturity when grown under control or salt stress conditions. The yield contributing traits like number of filled grains panicle ${ }^{-1}$, panicle length, plant height, spikelet fertility \%, 100-seed weight, and grain panicle ${ }^{-1}$ and yield were significantly reduced by the imposition of salt stress whereas the number of unfilled grains increased (Table 2). The reduction of yield attributing traits and yield due to salinity were also mentioned by other researchers [18, 59, 68,69]. Importantly, application of exogenous AsA was found to improve yield attributing traits and yields under salinity stress condition. The increase in yield and yield attributing traits due to AsA under salt stress were also found by other researchers [28]. Importantly the level of $\mathrm{H}_{2} \mathrm{O}_{2}$ increased significantly however the highest increase noted in the genotype those were salt susceptible. An increase in the MDA content in flag leaves at the reproductive stage in response salt stress was also reported by Moradi and Ismail [70] and similar results were found by the others $[49,61]$. Application of exogenous AsA was also found to lower $\mathrm{H}_{2} \mathrm{O}_{2}$ and MDA level under salt stress in other studies $[67,71,72]$.

The phenotypic correction (Table 3) study among the yield attributing and yield traits reflects a significant positive correlation of grain yield panicle ${ }^{-1}$ with the other morphological traits studied, whereas yield panicle ${ }^{-1}$ showed significant negative correlation with the biochemical traits measured (ROS and MDA). A similar positive correlation with yield was also reported by others [73-76]. The increase panicle length, filled grains and spikelet fertility ensures increased grain numbers, which contributes to increased grain yield. Furthermore, positive correlation of 100 -seed weight with yield indicates the importance of individual grain weight for increased yields. However, the number of unfilled grains panicle ${ }^{-1}$ showed a 


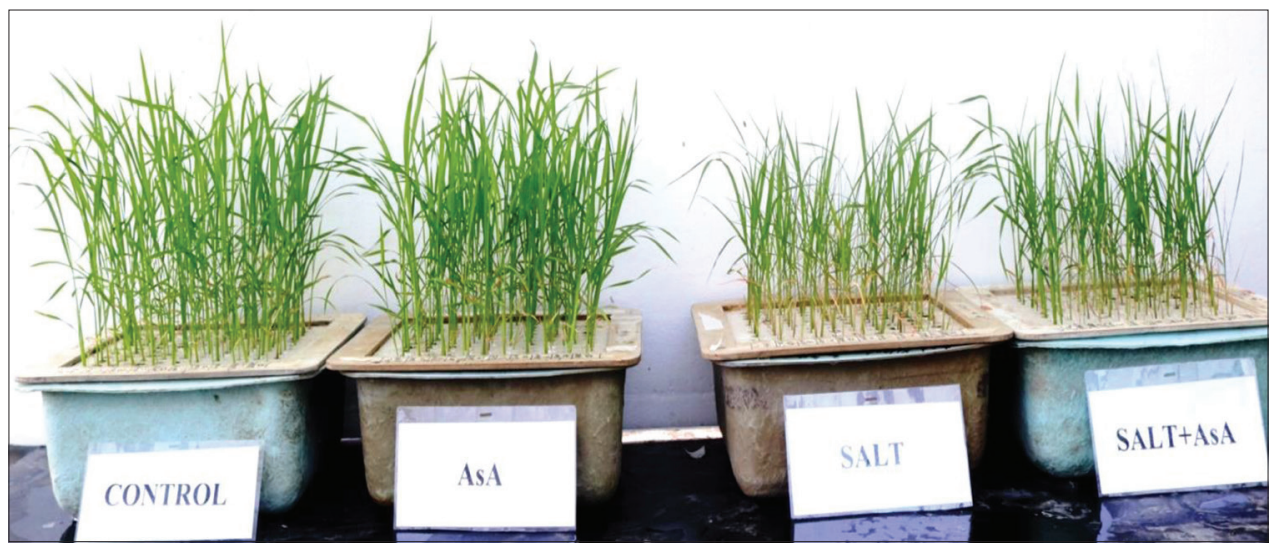

Figure 2: Phenological appearance of control, AsA-pretreated control, salt and AsA-pretreated salt-stressed seedlings after $96 \mathrm{~h}$ of salt stress $\left(10 \mathrm{dSm}^{-1}\right)$ treatment
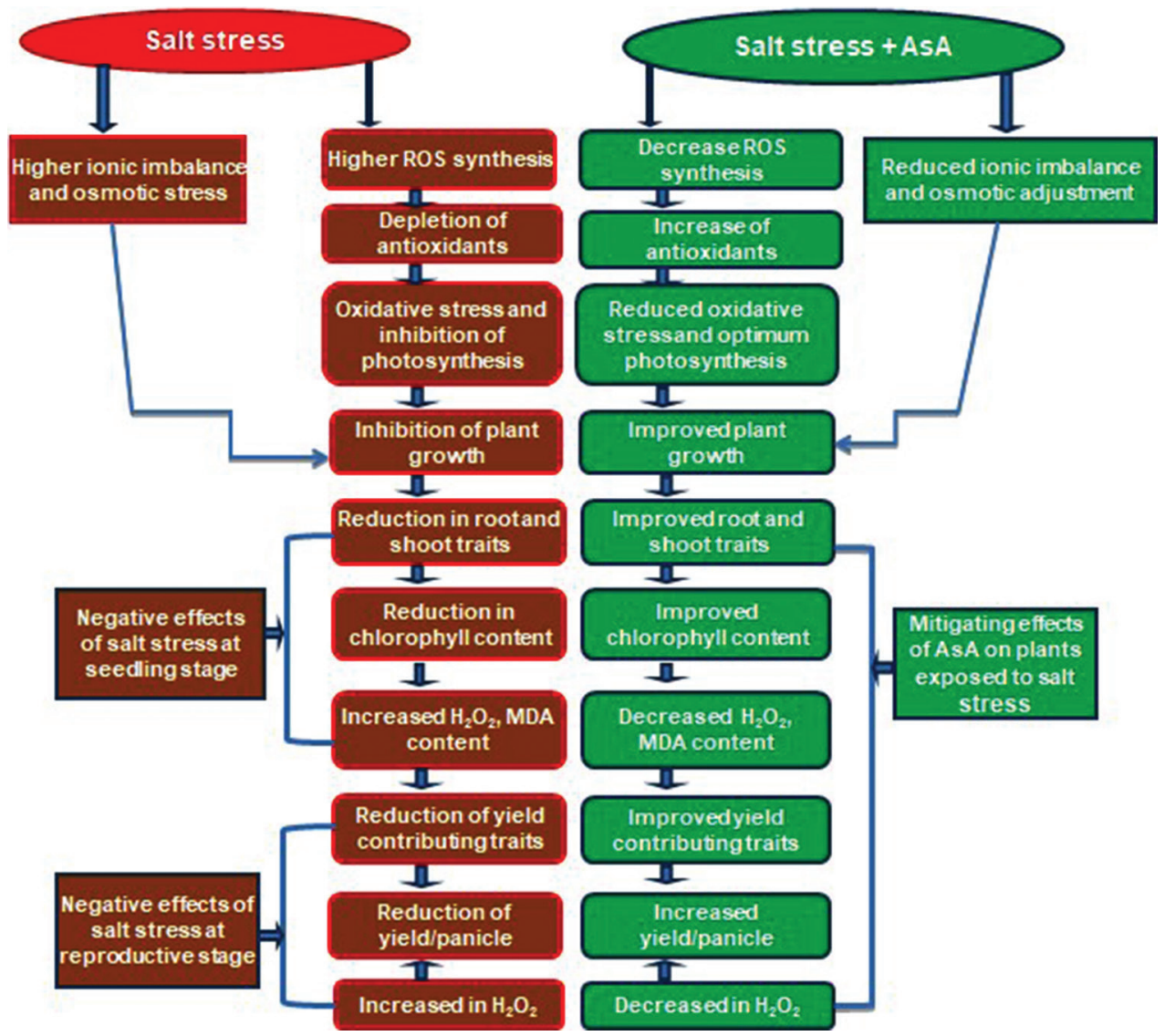

I

Improvedyield

contributing traits

L

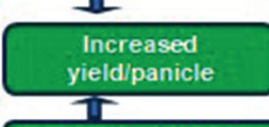

Decreased in $\mathrm{H}_{2} \mathrm{O}_{2}$

Figure 3: A schematic diagram showing the possible effects of AsA on the mitigation of salt stress in rice at the seedling and reproductive stages. Common negative effects of salt stress on plants are ionic imbalance and osmotic stress, which can trigger the accumulation of toxic compounds, e.g. reactive oxygen species (ROS), and depletion of antioxidants, e.g. AsA. These negatively affect plant growth and development, and consequently yield-contributing parameters and final yields. Application of exogenous AsA to plants under salt stress resulted in the maintenance of non-toxic levels of ROS, all of which contributed to the alleviation of salt-induced damage, leading to enhanced growth and development, and resulted higher yields

significant positive correlation with $\mathrm{H}_{2} \mathrm{O}_{2}$ and MDA. This result indicates that ROS and MDA levels might be the most important biochemical determinants of grain fertility. Increased level of ROS and MDA might be responsible for pollen and spikelet sterility which finally conferred the higher of number of unfilled grains panicle ${ }^{-1}$. A similar negative correlation with
ROS and rice grain yield were reported by Selote and KhannaChopra [22].

PCA provide an explanation and indication of the decisive component traits contributing to salt tolerance for the genotypes and treatments under study [77]. In this research 
experiment, PCA analysis disclosed that PCl is negatively correlated with number of unfilled grains panicle ${ }^{-1}$ and $\mathrm{H}_{2} \mathrm{O}_{2}$ (Table 4). This is in contrast to grain yield panicle ${ }^{-1}$, spikelet fertility, number of filled grains panicle ${ }^{-1}$, days to maturity, and 100-seed weight, which are positively correlated with PCl. Therefore grain yield panicle ${ }^{-1}$, spikelet fertility, number of filled grains panicle ${ }^{-1}$, days to maturity, and 100 -seed weight traits are positively associated with salinity tolerance in the present study. Under these hypothetical conditions, the $\mathrm{H}_{2} \mathrm{O}_{2}$ level was negatively correlated with spikelet fertility and 100-seed weight. The results suggest that plants with higher $\mathrm{H}_{2} \mathrm{O}_{2}$ level contents have lower spikelet fertility and 100-seed weights under saline conditions. Genotypes showing the highest values for the positively correlated traits for PCland PC2, were considered as highly saline tolerant genotypes and taking the place in the upper-right corner of the biplot. Genotypes with moderate values for $\mathrm{PCl}$ and $\mathrm{PC} 2$, located in the lower right and upper left corner of the graph, were considered as moderately salt tolerant and moderately salt sensitive, respectively (Figure 1). On the contrary, genotypes displaying the low values of positively correlated traits fall in the lower left portion of the biplot and were categorized as salt sensitive. Similar four major groups also categorized by Kakar et al. [78] using 74 rice genotypes. Under salt stress + AsA condition, only Binadhan-10, a salt tolerant rice genotype, is in the upper-right corner of the biplot, which has both positive effects for PCl and PC2 and this genotype is therefore classified as highly saline tolerant genotype.

Stress tolerance indices such as SSI, TOL, STI and YSI values estimated from grain yield panicle ${ }^{-1}$ were found to be effective in separating the susceptible and tolerant genotypes (Table 5). Among the stress tolerance indicators, Krishnamurthy et al. [79] suggested that higher values of TOL and SSI represent relatively more sensitivity to stress, thus a reduced value of TOL and SSI for a given genotype indicates the higher stability of the genotype in stress and no stress environments. Selection based on these two criteria favours genotypes with high yields under stress conditions. On the other hand, higher values of STI and YSI represent relatively a more tolerant genotype under salt stress than genotypes with lower values [80] and lower grain yield stability in stress conditions [81]. From the stress tolerance indices, FL-478 was the most susceptible genotype whereas Binadhan-10 was the most tolerant at reproductive stage of the seven rice genotypes tested. These selection indices are therefore effective for separating salt susceptible and tolerant genotypes. Additionally, individual ranking of the genotypes considering all of the traits at two different phases of plant growth indicates that tolerance at the reproductive and seedling stages are not correlated. Similar results were also reported by others $[68,82]$.

In conclusion, our studies clearly demonstrated that salinity at the seedlings stage and/or reproductive stages significantly impacted plant growth and development, and reduce yields and yield attributing traits. A clear genotypic difference in salt tolerance was observed with respect to developmental stage. Exogenous AsA application at the seedling and /or reproductive stages improved salinity tolerance in rice through the positive modulation of growth, yield and yield attributing traits (summarized in figure 3). The findings of our current study are useful for rice breeding programs and further research on molecular aspects of AsA-mediated salinity tolerance in rice is warranted, with the aim to enhance endogenous AsA levels using a genetic engineering approach. However, field trials with various concentrations of AsA and salinity levels will be needed to provide more definite information for management of salt stress in rice, as well as for the genetic manipulation of rice plants to enhance productivity.

\section{ACKNOWLEDGEMENT}

The authors would like to thank the University Grants Commission and Bangladesh Agricultural University for providing the research grant. Special thanks to Bangladesh Rice Research Institute and Bangladesh Institute of Nuclear Agriculture for providing the seeds and research facilities.

\section{CONFLICT OF INTEREST}

The authors declare that they have no conflict of interest.

\section{REFERENCES}

1. Machado RMA, Serralheiro RP. Soil salinity: effect on vegetable crop growth. Management practices to prevent and mitigate soil salinization. Horticulturae 2017; 3:30

2. Ahmadizadeh M, Vispo NA, Calapit-Palao CDO, Pangaan ID, Viña CD, Singh RK. Reproductive stage salinity tolerance in rice: a complex trait to phenotype. Indian Journal of Plant Physiology. 2016; 21(4): 528-536.

3. Saeed M, Adam DAH, Guo WZ, Zhang TZ. A cascade of recently discovered molecular mechanisms involved in abiotic stress tolerance of plants. OMICS: A Journal of Integrative Biology. 2012; 16: 188-199.

4. Ganie SA, Molla KA, Henry RJ, Bhat KV, Mondal TK. Advance in understanding salt tolerance in rice. Theoretical and Applied Genetics. 2019; 132(4): 851-870.

5. Solis CA, Yong MT, Vinarao R, Jena K, Holford P, Shabala L, Zhou M, Shabala S, Chen ZH. Back to the wild: on a quest for donors toward salinity tolerant rice. Frontiers in Plant Science 2020; 11:323.

6. SRDI. Saline Soils of Bangladesh, Soil Resources Development Institute (SRDI), MOA, Government of the People's Republic of Bangladesh. 2012

7. Dasgupta S, Hossain MM, Huq M, Wheeler D. Climate change, salinization and high-yield rice production in coastal Bangladesh Agricultural and Resource Economic Review. 2018; 47(1): 66-89.

8. Munns R, Tester M. Mechanisms of salinity tolerance. Annual Review of Plant Biology. 2008; 59:651-681

9. Moradi F, Ismail AM, Gregorio GB, Egdane JA. Salinity tolerance of rice during reproductive development and association with tolerance at the seedling stage. Indian Journal of Plant Physiology. 2003; 8: 105-116.

10. Mohammadi-Nejad G, Arzani A, Rezai AM, Singh RK, Gregorio GB. Assessment of rice genotypes for salt tolerance using microsatellite markers associated with the saltol QTL. African Journal of Biotechnology. 2008; 7(6): 730-736.

11. Kader MA, Lindberg S. Cytosolic calcium and $\mathrm{pH}$ signaling in plants under salinity stress. Plant Signaling and Behavior. 2010; 5: 233-238.

12. Hossain MA, Hasanuzzaman M, Fujita M. Coordinate induction of antioxidant defense and glyoxalase system by exogenous proline and glycinebetaine is correlated with salt tolerance in mung bean Frontiers of Agriculture in China. 2011; 5(1); 1-14.

13. Mostofa MG, Hossain MA, Fujita M. Trehalose pretreatment induces salt tolerance in rice seedlings: oxidative damage and co-induction of antioxidant defense and glyoxalase systems. Protoplsasma. 2015; 252(2): 461-475

14. Kamran M, Parveen A, Ahmar S, Malik Z, Hussain S, Chattha MS, Saleem MH, Adil M, Heidari P, Chen JT. An overview of hazardous 
impacts of soil salinity in crops, tolerance mechanisms, and amelioration through selenium supplementation. International Journal of Molecular Science. 2020; 21(1): 148.

15. Hu L, Liang W, Yin C, Cui X, Zheng J, Wang X, Hu J, Zhang D. Rice MADS3 regulates ROS homeostasis during late anther development. Plant Cell. 2011; 23: 515-533.

16. Rao PS, Mishra B, Gupta SR, Rathore A. Reproductive stage tolerance to salinity and alkalinity stresses in rice genotypes. Plant Breeding. 2008; 127: 256-261

17. Hussain BMN, Akram S, Raffi SA, Burritt DJ, Hossain MA. Exogenous glutathione improves salinity stress tolerance in rice (Oryza sativa L.). Plant Gene and Trait. 2016; 8: 1-17.

18. Chattopadhyay K, Nayak AK, Marndi BC, Poonam A, Chakraborty K, Sarkar RK. Novel screening protocol for precise phenotyping of salttolerance at reproductive stage in rice. Physiology and Molecular Biology of Plants. 2018; 24(6): 1047-1058.

19. Zeng L, Shannon MC. Salinity effects on seedling growth and yield components of rice. Crop Science. 2000; 40: 996-1003

20. Abdullah Z, Khan MA, Flowers TJ. Causes of sterility in rice under salinity stress. Journal of Agronomy and Crop Science. 2002; 187: 25-32.

21. Sarhadi E, Bazargani MM, Sajise AG, Abdolahi S, Vispo NA. Proteomic analysis of rice anthers under salt stress. Plant Physiology and Biochemistry. 2012; 58: 280-287.

22. Selote DS, Khanna-Chopra R. Drought-induced spikelet sterility is associated with an inefficient antioxidant defense in rice panicles. Physiologia Plantarum. 2004; 121: 462-471.

23. El-Shabrawi H, Kumar B, Kaul T, Reddy MK, Singla-Pareek SL, Sopory SK. Redox homeostasis, antioxidant defense, and methylglyoxal detoxification as markers for salt tolerance in Pokkali rice. Protoplasma. 2010; 245: 85-96.

24. Meloni DA, Oliva MA, Martinez CA, Cambraia J. Photosynthesis and activity of superoxide dismutase, peroxidase and glutathione reductase in cotton under salt stress. Environmental and Experimental Botany. 2003; 49: 69-76.

25. Gallie DR. I-Ascorbic acid: a multifunctional molecule supporting plant growth and development. Scientifica. 2013; 1: 1-24.

26. Shalata A, Neumann PM. Exogenous ascorbic acid (vitamin C) increases resistance to salt stress and reduces lipid peroxidation. Journal of Experimental Botany. 2001; 52(364): 2207-2211.

27. Amor NB, Jimenez A, Megdiche W, Lundqvist M, Sevilla F, Abdelly C. Response of antioxidant systems to $\mathrm{NaCl}$ stress in the halophyte Cakile maritima. Physiologia Plantarum. 2006; 126: 446-457.

28. Barus WA, Rauf $\mathrm{A}$, Rosmayati $\mathrm{CH}$. Improvement of salt tolerance in some varieties of rice by ascorbic acid application. International Journal of Science and Technology Research. 2015; 4(5): 235-237.

29. Roy PR, Tahjib-Ul-Arif M, Akter T, Ray SR, Sayed MA. Exogenous ascorbic acid and hydrogen peroxide alleviates salt-induced oxidative stress in rice (Oryza sativa L.) by enhancing antioxidant enzyme activities and proline content. Advances in Environmental Biology. 2016; 10(10): 148-155.

30. Hussain I, Siddique A, Ashraf MA, Rasheed R, Ibrahim M, Iqbal M, Akbar S, Imran M. Does exogenous application of ascorbic acid modulate growth, photosynthetic pigments and oxidative defense in okra (Abelmoschus esculentus (L.) Moench) under lead stress? Acta Physiologeae Plantarum. 2017; 39: 144

31. Upadhyaya CP, Akula N, Young KE, Chun SC, Kim DH, Park SW. Enhanced ascorbic acid accumulation in transgenic potato confers tolerance to various abiotic stresses. Biotechnology Letters. 2010; 32(2): 321-330.

32. Upadhyaya CP, Venkatesh J, Gururani MA, Asnin L, Sharma K, Ajappala H, Park SW. Transgenic potato overproducing L-ascorbic acid resisted an increase in methylglyoxal under salinity stress via maintaining higher reduced glutathione level and glyoxalase enzyme activity. Biotechnology Letters. 2011; 33: 2297-2307.

33. Zhang GY, Liu RR, Zhang CQ, Tang KX, Sun MF, Yan GH, Liu QQ. Manipulation of the rice L-galactose pathway: evaluation of the effects of transgene overexpression on ascorbate accumulation and abiotic stress tolerance. PloS One. 2015; 10(5): 125-870.

34. Sohag AAM, Tahjib-UI-Arif M, Polash MAS, Chowdhury MB, Afrin S, Burritt DJ, Hossain MA, Hossain MA. Exogenous glutathionemediated drought stress tolerance in rice (Oryza sativa L.) is associated with lower oxidative damage and favorable ionic homeostasis. Iranian Journal of Science and Technology Transaction
A. Science. 2020; 44: 955-971

35. Velikova V, Yordanov I, Edreva A. Oxidative stress and some antioxidant systems in acid rain-treated bean plants: protective role of exogenous polyamines. Plant Science. 2000; 151(1): 59-66.

36. Tahjib-Ul-Arif M, Afrin S, Polash MA, Akter T, Ray SR, Hossain MT, Hossain MA. Role of exogenous signaling molecules in alleviating salt-induced oxidative stress in rice (Oryza sativa L.): a comparative study. Acta Physiologiae Plantarum. 2019; 41(5): 69

37. Heath RL, Packer L. Photoperoxidation in isolated chloroplasts: I. Kinetics and stoichiometry of fatty acid peroxidation. Archives of Biochemistry and Biophysics. 1968; 125(1): 189-198.

38. Hossain MA, Hasanuzzaman M, Fujita M. Up-regulation of antioxidant defense and methylglyoxal detoxification system by exogenous glycinebetaine and proline confer tolerance to cadmium stress in mung bean seedlings. Physiology and Molecular Biology of Plants. 2010; 16(3): 259-272.

39. Fischer RA, Maurer R. Drought resistance in spring wheat cultivars. I. Grain yield responses. Australian Journal of Agricultural Research. 1978; 29(5): 897-912.

40. Rosielle AA, Hamblin J. Theoretical aspects of selection for yield in stress and non-stress environments. Crop Science. 1981: 21: 943-946.

41. Fernandez GC. Effective selection criteria for assessing plant stress tolerance. In: Proceeding of the International Symposium on Adaptation of Vegetables and other Food Crops in Temperature and Water Stress. 1992: 257-270

42. Bouslama M, Schapaugh WT. Stress tolerance in soybeans. I Evaluation of three screening techniques for heat and drought tolerance 1. Crop Science. 1984; 24(5): 933-937

43. Hoang TML, Tran TN, Nguyen TKN, Williams B, Wurm P, Bellairs S, Mundree S. Improvement of salinity stress tolerance in rice: challenges and opportunities. Agronomy 2016;6:54

44. Castillo EG, Tuong TP, Ismail AM, Inubushi K. Response to salinity in rice: comparative effects of osmotic and ionic stresses. Plant Production Science 2007; 10:159-170.

45. Gupta B, Huang B. Mechanism of salinity tolerance in plants: physiological, biochemical, and molecular characterization. International Journal of Genomics. 2014: 18

46. Urano D, Colaneri A, Jones AM. G $\alpha$ modulates salt-induced cellular senescence and cell division in rice and maize. Journal of Experimental Botany. 2014; 65(22): 6553-6561.

47. Potters G, Pasternak TP, Guisez Y, Jansen MAK. Different stresses, similar morphogenic responses: integrating a plethora of pathways. Plant Cell \& Environment. 2008; 32: 158-169.

48. Shrivastava P, Kumar R. Soil salinity: a serious environmental issue and plant growth promoting bacteria as one of the tools for its alleviation. Saudi Journal of Biological Science. 2015; 22(2): 123-131.

49. Omisun T, Sahoo S, Saha B, Panda SK. Relative salinity tolerance of rice cultivars native to North East India: a physiological, biochemical and molecular perspective. Protoplasma. 2018; 255(1): 193-202.

50. Ravikiran KT, Krishnamurthy SL, Warraich AS, Sharma PC. Diversity and haplotypes of rice genotypes for seedling stage salinity tolerance analyzed through morpho-physiological and SSR markers. Field Crop Research. 2018; 220: 10-18.

51. Tahjib-UI-Arif M, Sayed MA, Islam MM, Siddiqui MN, Begum SN, Hossain MA. Screening of rice landraces (Oryza sativa L.) for seedling stage salinity tolerance using morpho-physiological and molecular markers. Acta Physiologiae Plantarum. 2018; 40(4): 70.

52. Tariq R, Ali J, Arif M. Morphological screening and SalTol region based SSR markers analysis of rice (Oryza sativa L.) genotypes for salinity tolerance at seedling stage. International Journal of Agriculture and Biology. 2019; 21(1): 25-33

53. Hossain MA, Bhattacharjee, Armin SM, Qian P, Xin W, Li HY, Burritt DJ, Fujita M, Tran LSP. Hydrogen peroxide-priming modulates abiotic oxidative stress tolerance: insights from ROS detoxification and scavenging. Frontiers in Plant Science. 2015; 6: 420.

54. Formentin E, Sudiro C, Ronci MB, Locato V, Barizza E, Stevanato P Lo Schiavo $\mathrm{F}_{2} \mathrm{H}_{2} \mathrm{O}_{2}$ signature and innate antioxidative profile make the difference between sensitivity and tolerance to salt in rice cells. Frontiers in Plant Science. 2018; 9: 1549

55. Akram S, Siddiqui MN, Nahid Hussain BM, Bari MA, Mosof MG Hossain MA, Tran LSP. Exogenous glutathione modulates salinity tolerance of soybean (Glycine max L. Merrill) at reproductive stage. Journal of Plant Growth Regulation. 2017; 36: 877-888. 
56. AbdElgawad H, Zinta G, Hegab MM, Pandey R, Asard H, Abuelsoud W. High salinity induces different oxidative stress and antioxidant responses in maize seedlings organs. Frontiers in Plant Science. 2016; 7: 276 .

57. Xu Q, Xu X, Zhao Y, Jiao K, Herbert SJ, Hao L. Salicylic acid, hydrogen peroxide and calcium-induced saline tolerance associated with endogenous hydrogen peroxide homeostasis in naked oat seedlings. Plant Growth Regulation. 2008; 54(3): 249-259.

58. Willekens $\mathrm{H}$, Inze D, Van Montagu M, Van Camp W. Catalases in plants. Molecular Breeding. 1995; 1: 207-228

59. Saini P, Gani M, Kaur JJ, Godara LC, Singh C, Chauhan SS, Ghosh MK. Reactive oxygen species (ROS): a way to stress survival in plants. In Abiotic Stress-Mediated Sensing and Signaling in Plants: An Omics Perspective. 2018: 127-153.

60. Rahman A, Nahar K, Hasanuzzaman M. Fujita M. Calcium Supplementation Improves $\mathrm{Na}^{+} / \mathrm{K}^{+}$Ratio, antioxidant defense and glyoxalase systems in salt-stressed rice seedlings. Frontiers in Plant Science. 2016; 7: 609.

61. Chunthaburee S, Dongsansuk A, Sanitchon J, Pattanagul W, Theerakulpisut P. Physiological and biochemical parameters for evaluation and clustering of rice cultivars differing in salt tolerance at seedling stage. Saudi Journal of Biological Science. 2016; 23(4): 467-477.

62. Kordrostami M, Rabiei B, Kumleh HH. Biochemical, physiological and molecular evaluation of rice cultivars differing in salt tolerance at the seedling stage. Physiology and Molecular Biology of Plants. 2017; 23(3): 529-544

63. Wang $Y$, Zhao H, Oin H, Li Z, Liu H, Wang J, Zhang H, Quan R, Huang $R$, Zhang $Z$. The synthesis of ascorbic acid in rice roots plays an important role in the salt tolerance of Rice by scavenging ROS. International Journal of Molecular Science. 2018; 19: 3347.

64. Pharmawati M, Wijaya IMAS. Changes in growth, biochemical components and antioxidant genes expression in rice seedling (Oryza sativa L.) cultivar 'IR64'under salt stress. Indian Journal of Agricultural Research. 2019; 53(4): 478-482.

65. Schmidt R, Mieulet D, Hubberten HM, Obata T, Hoefgen R, Fernie AR, Fisahn J, Segundo BS, Guiderdoni E, Schippers JHM, MullerRoeber B. Salt-responsive ERF1 regulates reactive oxygen speciesdependent signaling during the initial response to salt stress in rice. Plant Cell. 2013; 25: 2115-2131.

66. Deinlein U, Stephan AB, Horie T, Luo W, Xu G, Schroeder JI. Plant salt-tolerance mechanisms. Trends in Plant Science. 2014; 19(6): 371-379.

67. Wang R, Liu S, Zhou F, Hua C. Exogenous ascorbic acid and glutathione alleviate oxidative stress induced by salt stress in the chloroplasts of Oryza sativa L. Zeitschrift fur Naturforschung. 2014; 69(5-6): 226-36.

68. Gerona MEB, Deocamp MP, Egdane JA, Ismail AM, Dionisio-Sese ML. Physiological responses of contrasting rice genotypes to salt stress at reproductive stage. Rice Science. 2019; 26(4): 207-219.
69. Rana MM, Takamatsu T, Baslam M, Kaneko K, Itoh K, Harada N, Sugiyama T, Ohnishi T, Kinoshita T, Takagi H. Salt tolerance improvement in rice through efficient SNP marker-assisted selection coupled with speed-breeding. International Journal of Molecular Science. 2019; 20: 2585.

70. Moradi F, Ismail AM. Responses of photosynthesis, chlorophyll fluorescence and ROS-scavenging systems to salt stress during seedling and reproductive stages in rice. Annals of Botany. 2007; 99(6): 1161-1173.

71. Azzedine F, Gherroucha H, Baka M. Improvement of salt tolerance in durum wheat by ascorbic acid application. Journal of Stress Physiology and Biochemistry. 2011; 7: 27-37.

72. Fercha A, Hocine G, Mebarek B. Improvement of salt tolerance in durum wheat by ascorbic acid application. Journal of Stress Physiology Biochemistry. 2011; 7: 27- 37.

73. Krishnamurthy SL, Sharma SK, Gautam RK, Kumar V. Path and association analysis and stress indices for salinity tolerance traits in promising rice (Oryza sativa L.) genotypes. Cereal Research Communication. 2014; 42(3): 474-483.

74. Naseer S, Kashif M, Ahmad HM, labal MS, Ali Q. Estimation of genetic association among yield contributing traits in aromatic and non-aromatic rice (Oryza sativa L) cultivars. Life Science Journal. 2015; 12(4): 68-73.

75. Parmita P, Goswami A. Correlation and character associations study in WA based rice hybrids. Indian Journal of Agriculture and Allied Science. 2015; 1(1): 35-37.

76. Ratna M, Begum S, Husna A, Dey SR, Hossain MS. Correlation and path coefficient analysis in basmati rice. Bangladesh Journal of Agricultural Research. 2015; 40(1): 153-161.

77. Negrão S, Schmöckel SM, Tester M. Evaluating physiological responses of plants to salinity stress. Annals of Botany. 2017; 119: $1-11$.

78. Kakar N, Jumaa SH, Redoña ED, Warburton ML, Reddy KR. Evaluating rice for salinity using pot-culture provides a systematic tolerance assessment at the seedling stage. Rice. 2019; 12(1): 57.

79. Krishnamurthy SL, Gautam RK, Sharma PC, Sharma DK. Effect of different salt stresses on agro-morphological traits and utilisation of salt stress indices for reproductive stage salt tolerance in rice. Field Crop Research. 2016; 190: 26-33

80. Anshori MF, Purwoko BS, Dewi IS, Ardie SW, Suwarno WB, Safitri H Determination of selection criteria for screening of rice genotypes for salinity tolerance. SABRAO Journal of Breeding and Genetics. 2018; 50(3): 289-294.

81. Girma BT, Ali HM, Gebeyaneh AA. Effect of salinity on final growth stage of different rice (Oryza sativa L.) genotypes. Asian Journal of Agricultural Research. 2017; 11: 1-9.

82. Mansuri RM, Shobbar ZS, Jelodar NB, Ghaffari MR, Nematzadeh GA Asari S. Dissecting molecular mechanisms underlying salt tolerance in rice: a comparative transcriptional profiling of the contrasting genotypes. Rice. 2019; 12(1): 13 